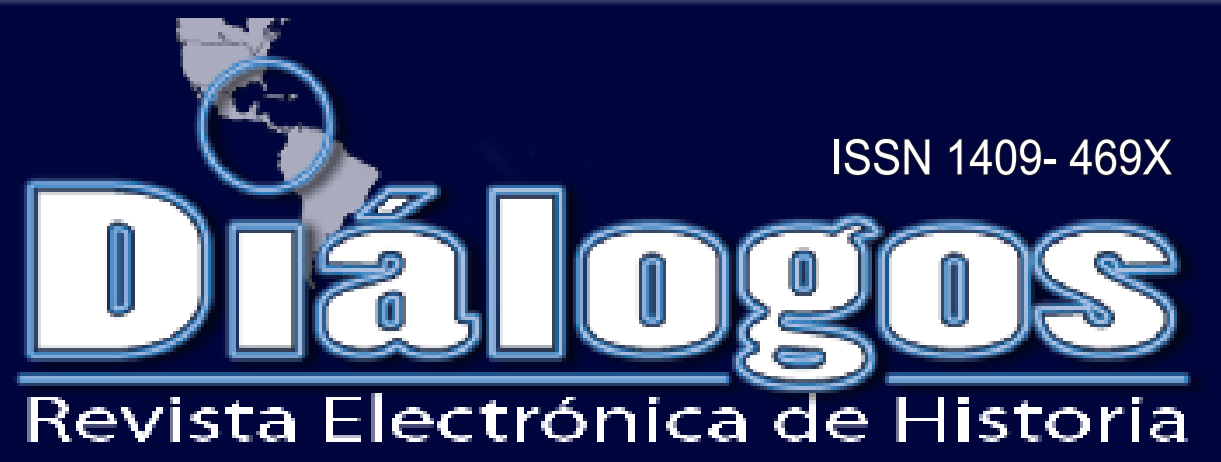

Escuela de Historia. Universidad de Costa Rica Vol. 13 No. 1 Febrero - Agosto 2012

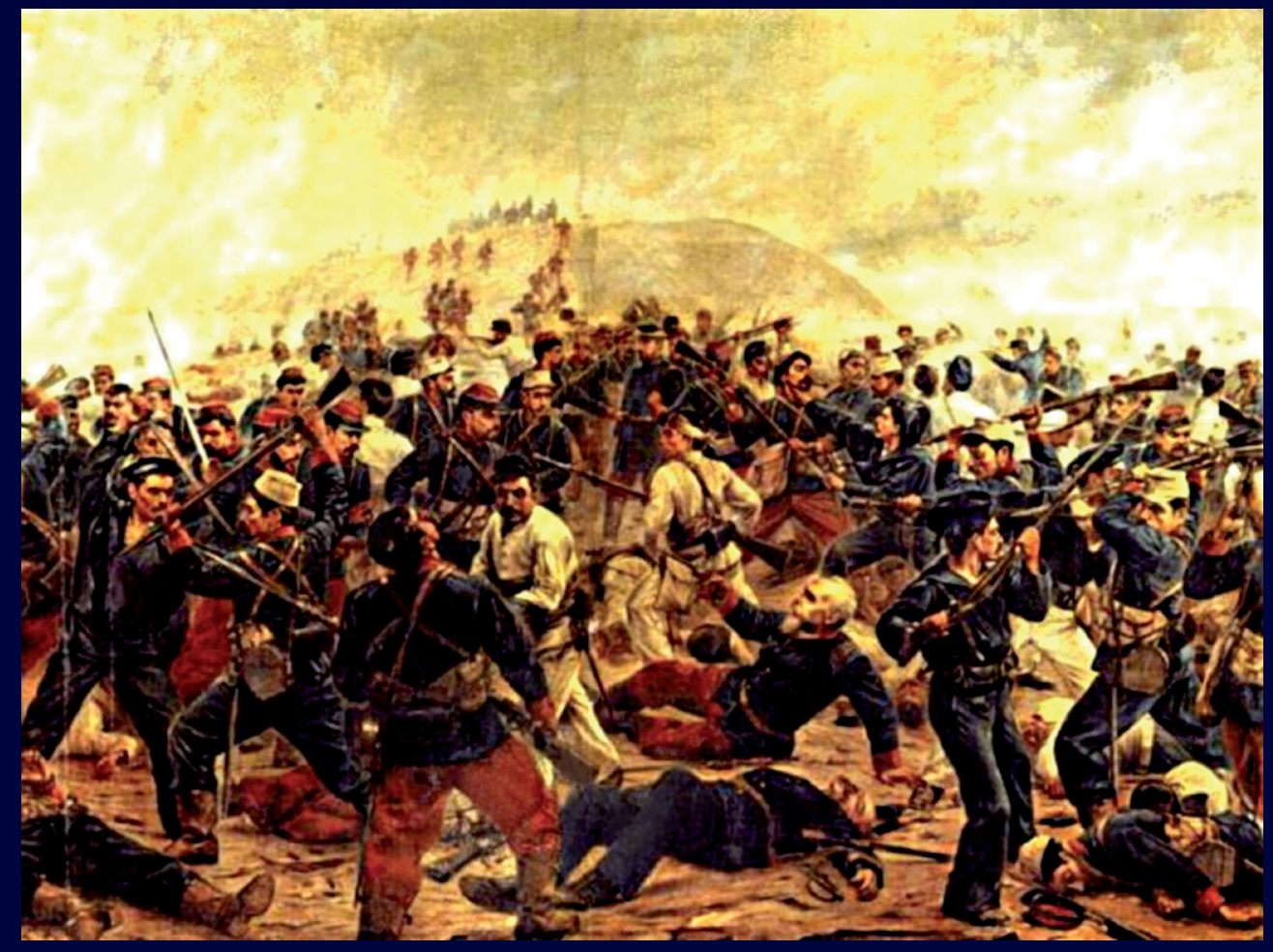

INTEGRACIÓN DE CUERPOS SOCIALES EN EL ESPACIO RURAL DEL CHACO ENTRE CICLOS ECONÓMICOS DIFERENCIADOS. VIDA LABORAL DE "TIPOS" EMBLEMÁTICOS, Y SU IMPRONTA EN LA IDENTIDAD POPULAR.

Oscar Ernesto Mari

Director de la Revista: Dr. Juan José Marín Hernández juan.marinhernandez@ucr.ac.cr

Editor académico: Dr. Ronny Viales Hurtado - ronny.viales@ucr.ac.cr Editor técnico: M.Sc. Marcela Quirós G. - marcela.quiros@ucr.ac.cr Asistente: Cindy Chaves U. http://historia.fcs.ucr.ac.cr/dialogos.htm 


\section{Miembros del Consejo Editorial:}

Dr. Juan José Marín Hernández, Catedrático. Director del Centro de Investigaciones Históricas de América Central. Universidad de Costa Rica.

Dr. Ronny Viales Hurtado. Catedrático. Historia Económica y Social. Universidad de Costa Rica. Director de la Escuela de Historia. ronny.viales@ucr.ac.cr

Dr. Guillermo Carvajal. Geografía Humana. Universidad de Costa Rica.

MSc. Francisco Enríquez. Historia Social. Universidad de Costa Rica.

MSc. Bernal Rivas Especialista en Archivística. Universidad de Costa Rica.

MSc. Ana María Botey. Historia de los movimientos sociales. Universidad de Costa Rica.abotey@gmail.com

\section{Miembros del Consejo Asesor Internacional:}

Dr. José Cal Montoya. Universidad de San Carlos de Guatemala.jecalm@correo.url.edu.gt

Dr. Juan Manuel Palacio. Universidad Nacional de San Martín.jpalacio@unsam.edu.ar

Dr. Eduardo Rey. Universidad de Santiago de Compostela.ereyt@usc.es

Dr. Heriberto Cairo Carou. Departamento de Ciencia

Política y de la Administración III - Universidad

Complutense de Madrid. hcairoca@cps.ucm.es

Dra. Rosa de la Fuente. Departamento de Ciencia Política y de la Administración III Universidad Complutense de Madrid rdelafuente@cps.ucm.es

Dr. Javier Franzé. Departamento de Ciencia Política y de la Administración III Universidad Complutense de Madrid. javier.franze@cps.ucm.es

Dr. Jaime Preciado Coronado Departamento de Estudios Ibéricos y Latinoamericanos. Universidad de Guadalajara japreco@hotmail.com

Dr. Gerónimo de Sierra. Vicerrector de la Universidade Federal da Integração Latino-Americana (UNILA) y Departamento de Sociología, Facultad de Ciencias Sociales de la Universidad de la República. geronimo@fcs.edu.uy

Dr. Antonio Palazuelos. Departamento de Ciencia Política y de la Administración III - Universidad Complutense de Madrid. palazuelosa@cps.ucm.es

Dr. Werner Mackenbach. Universidad Potsdam. werner.mackenbach@uni-potsdam.de
Dr. Guillermo Castro. Ciudad del Saber Panamá. gcastro@cdspanama.org

Dra. Natalia Milanesio. University of Houston.

nmilane2@Central.UH.EDU

Dr. Ricardo González Leandri. Consejo Superior de Investigaciones Científicas - España.

rgleandri@gmail.com

Dra. Mayra Espina. Centro de Estudios Psicológicos y Sociológicos, La Habana. mjdcips@ceniai.inf.cu

Dra. Montserrat Llonch. Departamento de Economía e Historia Económica Universidad Autónoma de Barcelona montserrat.llonch@uab.es

Dra. Estela Grassi. Universidad de Buenos Aires. estelagrassi@gmail.com

Portada:

Óleo de Juan Lepiani titulado Batalla de Arica (1880-Museo de los Combatientes de Arica) : Volumen 13- No. 1, artículo 2 "Sois vosotros valientes héroes. Somos nosotros simples humanos"... de David Angelo Coronado Canales. Fuente: http://members.tripod.com/ Guerra_del_Pacifico/ARICA3. html

"Diálogos Revista Electrónica de Historia" se publica desde octubre de 1999.

\section{Diálogos está en los siguientes repositorios:}

Dialnet

http://dialnet.unirioja.es/servlet/revista?tipo_busqueda=CODIGO\&clave_revista=3325

Latindex

http://www.latindex.unam.mx/larga.php?opcion=1\&folio=12995;

REDALYC

http://redalyc.uaemex.mx/src/inicio/FrmBusRevs2.jsp?iEdoRev=2\&cvepai=11

LANIC

http://lanic.utexas.edu/la/ca/cr/indexesp.html;

Repositorio de Revistas Universidad de Costa Rica http://www.latindex.ucr.ac.cr/

Directorio y recolector de recursos digitales del Ministerio de Cultura de España

http://roai.mcu.es/es/inicio/inicio.cmd

DOJAC Directory of open access \& Hybrid journals http://www.doaj.org/doaj?func=byTitle\&hybrid=1\&query=D

Biblioteca de Georgetown

http://library.georgetown.edu/newjour/d/msg02735.html

Asociación para el Fomento de los Estudios Históricos en Centroamérica

http://afehc.apinc.org/index.php?action=fi_aff\&id=1774 
Universidad de Saskatchewan, Canadá

https://library.usask.ca/ejournals/view/1000000000397982

\section{Monografias}

http://www.monografias.com/Links/Historia/more12.shtm

\section{Hispanianova}

http://hispanianova.rediris.es/general/enlaces/hn0708.htm

Universidad del Norte, Colombia

http://www.uninorte.edu.co/publicaciones/memorias/enlaces.html

Universidad Autónoma de Barcelona

http://seneca.uab.es/historia/hn0708.htm

Repositorio Invenia - Gestión del Conocimiento

http://www.invenia.es/oai:dialnet.unirioja.es:ART0000086144

Enlace Académico

http://www.enlaceacademico.org/biblioteca/revistas-en-formato-digital-centroamerica/

\section{Electronic Resources}

http://sunzi1.lib.hku.hk/ER/detail/hkul/3987318

Revistas académicas en texto completo

http://web.prw.net/ vtorres/

\section{Diálogos se anuncia en las siguientes} instituciones y sitios académicos:

\section{Maestroteca}

http://www.maestroteca.com/detail/553/dialogos-revista-electronica-de-historia.html

\section{Biblioteca de Georgetown}

http://library.georgetown.edu/newjour/d/msg02735.htm
Asociación para el Fomento de los Estudios Históricos en Centroamérica

http://afehc.apinc.org/index.php?action=fi_aff\&id=1774

Universidad de Saskatchewan, Canadá

https:/library.usask.ca/ejournals/view/1000000000397982

\section{Monografias}

http://www.monografias.com/Links/Historia/more12.shtml

Hispanianova

http://hispanianova.rediris.es/general/enlaces/hn0708.htm

Universidad del Norte, Colombia

http://www.uninorte.edu.co/publicaciones/memorias/enlaces.html

\section{Universidad Autónoma de Barcelona}

http://seneca.uab.es/historia/hn0708.htm

Repositorio Invenia - Gestión del Conocimiento http://www.invenia.es/oai:dialnet.unirioja.es:ART0000086144

\section{Enlace Académico}

http://www.enlaceacademico.org/biblioteca/revistas-en-formato-digital-centroamerica/

\section{Electronic Resources}

http://sunzi1.lib.hku.hk/ER/detail/hkul/3987318

Revistas académicas en texto completo http://web.prw.net/ vtorres/

La revista electrónica Diálogos es financiada por la Vicerrectoría de Investigación de la Universidad de Costa Rica
Citado en Dialnet - Latindex-

Redilac- Directorio y recolector de recursos digitales del

Ministerio de Cultura de España cc) creative 



\title{
INTEGRACIÓN DE CUERPOS SOCIALES EN EL ESPACIO RURAL DEL CHACO ENTRE CICLOS ECONÓMICOS DIFERENCIADOS. VIDA LABORAL DE "TIPOS" EMBLEMÁTICOS, Y SU IMPRONTA EN LA IDENTIDAD POPULAR.
}

\author{
Palabras claves \\ Chaco, territorio, identidad, hacheros, cosecheros
}

\section{Keywords}

Chaco, territory, identity, rural social types

Fecha de recepción: 24 enero 2012 - Fecha de aceptación: 30 enero 2012

\begin{abstract}
Resumen
La ocupación del Chaco Austral Argentino entre fines del siglo XIX y primeras décadas del XX, fue impulsada por sucesivas etapas colonizadoras que acompañaron la alternancia ciclos económicos diferenciados. En cada uno de estos momentos, que se dieron en ámbitos geográficos diferentes dentro del Territorio, fueron formándose cuerpos sociales particulares que aportaron los primeros rasgos identitarios a esta sociedad en formación. Dentro de éstos, surgieron "tipos sociales" que motivaron las primeras imágenes con que la sociedad nacional identificó al Chaco. Las condiciones de vida y trabajo, y el aporte cultural de algunos sectores representativos del ámbito rural del Chaco en esta época, son temas abordados en el presente artículo.
\end{abstract}

\begin{abstract}
The occupation of the Southern Chaco Argentine between ends of the nineteenth century and early decades of the 20th, was boosted by successive phases colonizers that they accompanied differentiated economics cycles. In each one of these moments, that were given in different geographic areas within the Territory, went forming social groups individuals that contributed the first identity traits to this society in training. Within these, emerged social types that motivated first images with that the domestic society identified to Chaco. Living conditions and work, and it contributes the cultural of some sectors representing the rural field of Chaco in this period, are issues addressed in the current article.
\end{abstract}




\section{INTEGRACIÓN DE CUERPOS SOCIALES EN EL ESPACIO RURAL DEL CHACO ENTRE CICLOS ECONÓMICOS DIFERENCIADOS. VIDA LABORAL DE "TIPOS" EMBLEMÁTICOS, Y SU IMPRONTA EN LA IDENTIDAD POPULAR.}

Oscar Ernesto Mari

\section{INTRODUCCIÓN}

El Chaco Austral Argentino fue uno de los últimos espacios territoriales en ser incorporados de manera efectiva al Estado organizado. El proceso, iniciado al término de la guerra de la Triple Alianza ${ }^{1}$ y luego de la definición de las fronteras externas en la región, atravesó distintas circunstancias en las que se alternaron diversos mecanismos para asegurar el control en áreas hasta entonces bajo dominio indígena; garantizar la ocupación del espacio y la colonización, e insertar de manera sustentable a este Territorio en el esquema económico entonces imperante.

En términos generales, podría decirse que dicho proceso se materializó en el período transcurrido entre las dos últimas décadas del siglo XIX, y las cuatro primeras del siglo XX. En dicho lapso este espacio sufrió cambios en su régimen político-institucional, pero sobre todo, notables transformaciones en el orden económico y demográfico.

Desde 1884 hasta 1951 fue uno de los Territorios Nacionales creados simultáneamente mediante la ley $\mathrm{N}^{\mathrm{o}} 1532$, por lo que recibió una organización y un status jurídico semejante, es decir, fue una unidad territorial enteramente dependiente del Poder Central, que designaba a su vez, a los funcionarios de actuación local.

En el orden económico, el Chaco se insertó inicialmente en el sistema nacional dentro del modelo primario exportador mediante la actividad forestal, que luego, a partir de los años 1920, sería reemplazada por las actividades agrícolas, lideradas principalmente por la producción algodonera. Ambas actividades marcaron de tal modo la evolución del Chaco, que hasta la actualidad se distinguen sin mayores reparos dos ciclos económico-sociales claramente definidos para la época territoriana: el forestal, y el algodonero. ${ }^{2}$

Desde luego, por las características y la dinámica propia de cada uno de estos ciclos se generaron a su vez dos épocas con cuerpos sociales y ritmos de vida distintos, que a la sazón, ofrecieron las primeras y más perdurables imágenes del Chaco registradas por la sociedad nacional.

Durante el ciclo forestal la vida giró en torno a las actividades extractivas (maderas y tanino) y se desarrolló fundamentalmente en el sector sud-oriental del 
Territorio. La incipiente sociedad de entonces estuvo conformada por los inmigrantes europeos arribados en la primera etapa colonizadora; por paraguayos y correntinos ${ }^{3}$ que por proximidad geográfica participaron de este proceso, y (ya como un sector marginal), por los indígenas pacificados que no tuvieron otra opción que la de asimilarse como asalariados dentro de este esquema.

Las "imágenes" más reconocidas del Chaco de esta época fueron sus inmensas riquezas forestales, su clima inhóspito, e intrépidos pioneros que se aventuraban a adentrarse en comarcas de -aún impredecibles- parcialidades indígenas, y a convivir con grupos humanos poco habituados a normas de civilización.

Posteriormente, durante el ciclo algodonero, con la ocupación plena del espacio interior desde principios de la década de 1920, el foco de atención se trasladó al centro-oeste del Territorio, donde las huestes de la segunda corriente inmigratoria compuesta fundamentalmente por inmigrantes provenientes de la Europa del Este se abocaron preferentemente al cultivo algodonero, inaugurándose una nueva etapa en la que la colonización agrícola generó nuevos "tipos sociales" que identificaron al Chaco por mucho tiempo.

Las imágenes de esta época fueron, a diferencia del ciclo anterior, las de un Territorio en franco ascenso que comenzaba a exhibirse en exposiciones nacionales; chacras cubiertas de níveos capullos; un modelo económico basado en explotaciones productivas que reemplazaban a las extractivas; y los representantes típicos del momento: colonos, cosecheros, acopiadores, y prósperos comerciantes de ramos generales, entre otros.

En ambos períodos y en los respectivos ámbitos de preeminencia de cada una de estas actividades, fueron germinando -asociados a éstas- los primeros rasgos identitarios de una sociedad altamente heterogénea. ${ }^{4}$

En este trabajo habremos de referirnos sintéticamente a las primeras etapas de la ocupación del espacio en este Territorio; caracterizaremos cualitativamente al componente humano inicial, para situarnos luego en el período comprendido entre las décadas del veinte y cuarenta del siglo XX, procurando recrear las condiciones en las que se desarrollaron las principales actividades económicas, e ir perfilando los "tipos" o sectores vinculados que, por mayoritaria presencia, temperamento, o tradiciones, marcaron una fuerte impronta en la identidad de este cuerpo social en construcción. ${ }^{5}$ Asimismo intentaremos captar la percepción de la clase dirigente sobre el impacto laboral, demográfico, y las condiciones de vida de estos grupos en el Territorio. No pretendemos agotar en esta instancia el abanico de ejemplos, sino más bien, enfocarnos en la descripción de la vida cotidiana de aquellos sujetos sociales que sin haber tenido adecuada valoración en la historiografía tradicional, han dejado sin embargo su huella inconfundible en el entretejido cultural de las clases populares del Chaco. ${ }^{6}$ 


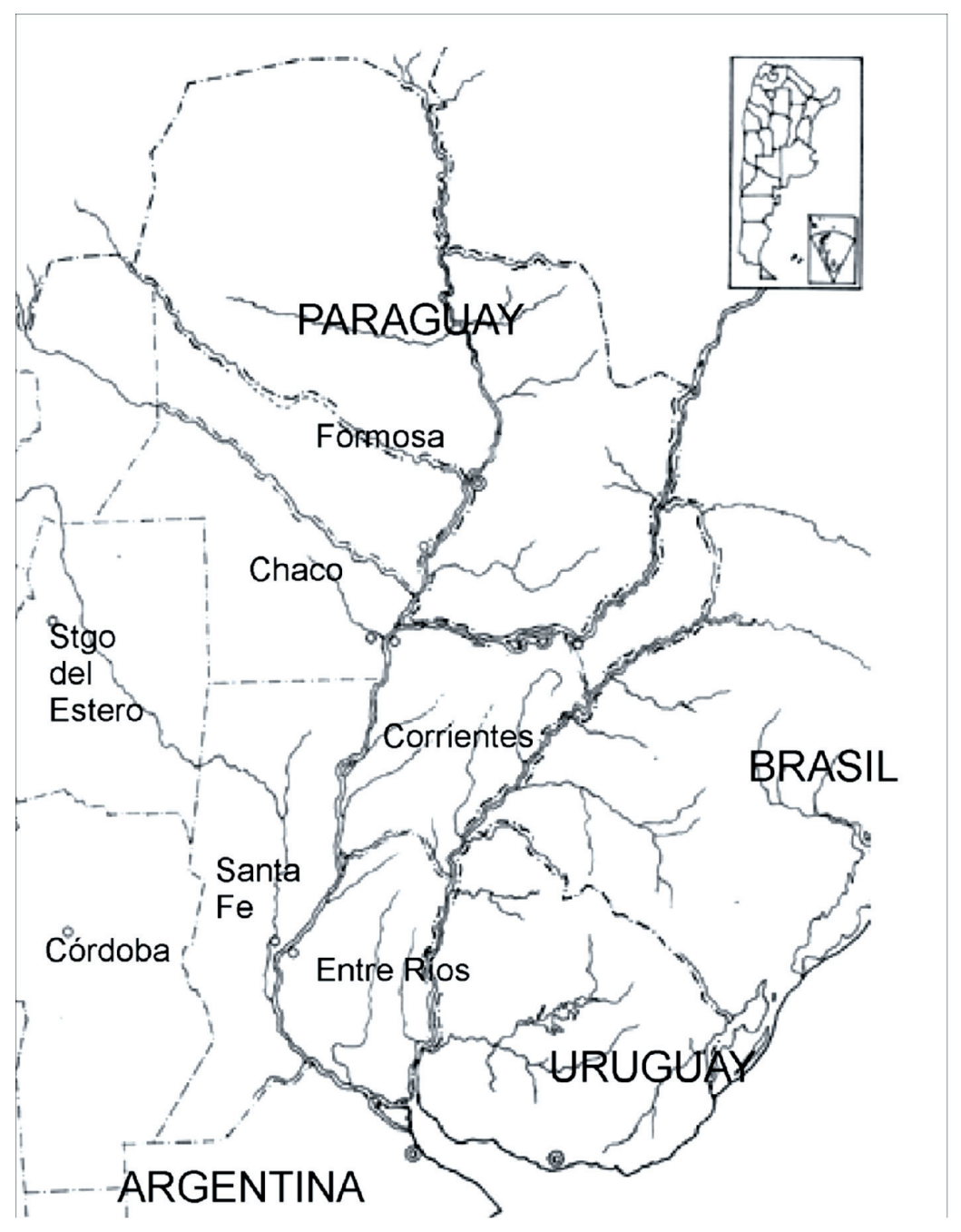

Figura 1. Ubicación de la actual provincia de Chaco en la República Argentina

\section{LA OCUPACIÓN DEL ESPACIO Y EL PROCESO DE FORMACIÓN DE UNA SOCIEDAD HETEROGÉNEA}

La primera etapa de ocupación del espacio en el Chaco austral se inició casi al mismo tiempo en que se definían las fronteras externas con el Paraguay. La misma comenzó a fines del siglo XIX en el sector oriental, para extenderse luego -ya en las primeras décadas del siglo XX- hacia la zona centro-oeste, en una campaña que supuso la intervención del ejército, la construcción de líneas férreas troncales, y el fomento de la colonización agrícola.

En ambas etapas, la ocupación se apoyó en la inmigración interna y externa, atraídas por la entrega de la tierra pública o por la propia dinámica de las actividades 
forestales primero, y agrícolas posteriormente. Esta inmigración tuvo fases introductorias alternadas, orígenes diversos, y una composición diferente, de acuerdo al rol que desempeñaron los grupos en las respectivas zonas y/o rubros de explotación.

El primer contingente de inmigrantes arribó en 1878 a la zona oriental a las inmediaciones de lo que luego sería la capital del Chaco (Resistencia), y con este primer grupo proveniente del norte de Italia se inició la colonización agrícola en este sector del Territorio.

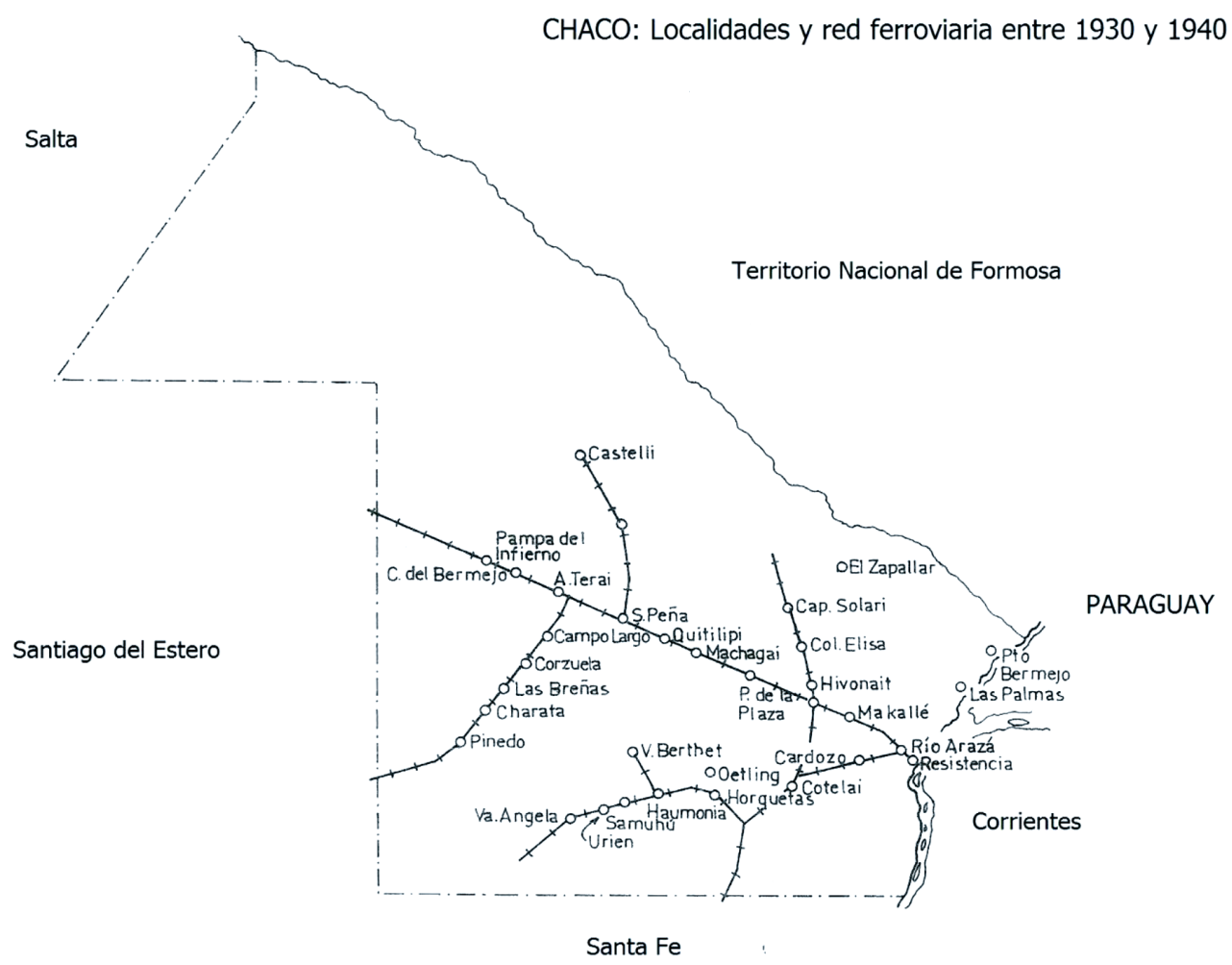

Figura 2. Territorio Nacional del Chaco entre 1930 y 1940.

Fuente: Elaboración del autor.

Pero en su afán de acelerar la ocupación del Territorio, el Estado nacional entregó en los años subsiguientes vastas extensiones de tierra en el área circundante, que estarían destinadas a la explotación forestal. Como consecuencia de una dispendiosa política de concesiones se formó alrededor de las iniciales colonias agrícolas una "corona" de latifundios que quedaron en manos de grandes empresas dedicadas a la extracción de tanino de la principal especie arbórea de la región: el quebracho colorado. Estas empresas operaron prácticamente sin controles, manejando los precios y las relaciones laborales con discrecionalidad. 
Esta actividad, que dio inicio al llamado "ciclo forestal" en el Chaco, atrajo numerosos contingentes de jornaleros provenientes de la vecina provincia de Corrientes, los que juntamente con paraguayos e indígenas asimilados, constituyeron la base de la fuerza laboral que movilizó a este rubro y al de la industrialización de la caña de azúcar, que también prosperó en el sector oriental. Estos grupos humanos quedaron afincados aún después de iniciada la declinación taninera al finalizar la primera guerra mundial.

De este modo, colonos italianos -y españoles luego-, así como asalariados correntinos, paraguayos e indígenas pacificados, constituirán la base del poblamiento en la zona oriental durante esta primera etapa de ocupación del espacio ocurrida entre las dos últimas décadas del siglo XIX y la primera del siglo XX.

La necesidad del Estado de incorporar plenamente el espacio interior del Chaco corrigiendo al mismo tiempo las imperfecciones de la acción colonizadora inicial, llevó a impulsar un nuevo emprendimiento poblador hacia el centro-oeste.

Lo que se conoce como la "segunda etapa" colonizadora en el Chaco, que normalmente está asociada al cultivo de algodón, y que comenzó a mostrarse con toda claridad a principios de la década del veinte, es un proceso que en realidad tiene sus orígenes en el primer lustro del siglo XX.

En 1908 se dictó la ley 5559 llamada de "fomento de los Territorios Nacionales", que en el caso específico del Chaco, tendría sin duda una importancia decisiva. Por la misma se autorizaba la construcción de ramales ferroviarios troncales que atravesarían el Chaco desde el sureste, hacia el centro, suroeste, y noroeste; y también la venta de la tierra fiscal circundante para amortizarlos.

El tendido de rieles comenzó en 1909 y para 1914 las obras estaban terminadas. Simultáneamente una nueva campaña militar redujo a los grupos indígenas aún no asimilados al dominio blanco, de modo tal que para 1915, la totalidad de la superficie del Territorio se hallaba ya bajo control del Estado. En el espacio ganado se iniciaba un proceso de ocupación civil, y un conjunto de pueblos y parajes surgieron alrededor de las estaciones ferroviarias emplazadas.

Por el decreto del 11 de julio de 1921 se libraron más de 1 millón de hectáreas a la colonización agrícola, creándose un conjunto colonias en el centro y sudoeste, y previendo un régimen de adjudicación de la tierra más controlado que en las etapas anteriores.

En esta época se presentaron condiciones inmejorables para el poblamiento exitoso del interior del Chaco. El precio del algodón en los mercados internacionales aumentó considerablemente, y el área agrícola recientemente incorporada reunía condiciones óptimas para su cultivo. Estaba abierta la entrada a la inmigración extranjera, y se disponía de una flamante red ferroviaria capaz de sacar la producción.

A partir de este momento se advierte una modificación fundamental en la fisonomía económico-social del Chaco, y puede hablarse con propiedad de un cambio 
de ciclo. Si bien la actividad extractivo-forestal anteriormente dominante nunca desaparecería, desde 1918 había iniciado un período declinante, y aunque gozó de algunos repuntes temporarios, ya no volvería a tener la importancia de antes. La preponderancia que adquirió el cultivo algodonero y sus efectos dinamizadores, permiten marcar aproximadamente en esta época, una transición entre el llamado ciclo forestal o del tanino, y el nuevo ciclo algodonero.

Los factores enunciados y la disponibilidad de mano de obra -liberada como consecuencia de la declinación de la actividad taninera- propiciarían a comienzos de los años 1920 el contexto necesario para pasar de una economía extractiva a una productiva.

Una reimpulsada política inmigratoria incentivó la entrada de nuevos contingentes pobladores, que provendrán ahora mayoritariamente de la Europa del Este. En esta nueva oleada colonizadora arribaron al Chaco unos 16.000 inmigrantes europeos entre 1923 y 1930, y unos 4.200 se agregarían más tarde, entre los años 1931 y 1936.

El apogeo del cultivo ocurrido entre la segunda mitad de la década del veinte y la totalidad de la siguiente generó un paisaje agrario muy peculiar donde todo giró en torno al algodón. Las tareas de cultivo y zafra, íntegramente manuales, propiciaron además la periódica afluencia de nutridos contingentes humanos que se dedicaron a estas labores. Esta fuerza laboral provino esencialmente de las provincias colindantes, y también del Paraguay.

Los años transcurridos desde 1920 hasta 1934 cambiarían la fisonomía demográfica del Chaco. De 60.500 habitantes se pasa a 214.000 en este período, y para 1936 se calculaban ya en 314.000 , registrándose así el crecimiento poblacional más alto de todas las jurisdicciones argentinas en la época.

De este modo y en pocos años, el cultivo exitoso de algodón convirtió al Chaco en una de las jurisdicciones más prósperas de la Argentina, atrayendo con su dinámica a miles de inmigrantes internos y externos, y a emprendedores de diversos oficios que deseaban encontrar un futuro promisorio en este espacio.

No obstante, el vértigo de este proceso y la continua atracción humana que su propio éxito generó, serían a su vez y simultáneamente los inductores de problemas que las autoridades locales o nacionales no alcanzaron a resolver en tiempo y forma. El desborde de la estructura administrativa y de servicios causado por la extraordinaria afluencia de pobladores y trabajadores temporarios fue una constante, y los esfuerzos por adaptarla a un cambiante escenario socioeconómico que se modificaba año tras año, serían decididamente insuficientes o ineficaces.

Ahora bien; la caracterización de este nuevo cuerpo social en formación requiere algunas precisiones cuantitativas y cualitativas de estos contingentes heterogéneos, cuya procedencia, épocas y motivos de arribo han sido sintetizados, para poder detenernos luego en el análisis de las condiciones de vida y el comportamiento 
que tuvieron los diversos grupos sociales, especialmente en los ámbitos rurales, ya que a la sazón, fueron éstos los espacios receptores por excelencia.

Durante la época territoriana la población del Chaco estuvo mayoritariamente radicada en estos ámbitos, y su incremento se produjo tanto por el crecimiento natural como por el significativo aporte de la inmigración externa e interna ocurrida especialmente durante las décadas del veinte y treinta. En este período la natalidad se mantuvo alta (más de un 30 por mil), frente a una mortalidad que osciló entre el 9 y el 10 por mil, lo cual dejaba regularmente un saldo positivo considerable.(Maeder, 1997: 210-211)

Respecto a la inmigración extranjera, su caudal fue importante aunque declinó a partir de la segunda mitad de la década del treinta, en particular, el correspondiente a los europeos. En este sentido cabe insistir en la distinción de inmigrantes europeos y la de americanos, destacando entre estos últimos a los paraguayos, que superaron ampliamente a los contingentes provenientes de otros países limítrofes, como uruguayos y brasileños, por ejemplo.

En el caso de los europeos, su afluencia se produjo especialmente al término de la primera guerra mundial, sólo que durante esta segunda corriente inmigratoria, el tradicional aporte de españoles e italianos fue reemplazado por europeos del Este, que llegaron a representar el 50\% de los arribados desde ese continente, según datos del censo territorial de 1934. (Castells, 1934: 114)

En cuanto a la inmigración interna, es decir, la proveniente de otras regiones de Argentina cabe indicar que su cifra creció también considerablemente (de 21.426 en 1914, a 146.365 en 1947), y en este sentido es de destacar que los nativos de las vecinas provincias de Corrientes, Santiago del Estero y Santa Fe constituyeron los grupos mayoritarios, en ese mismo orden.

Esta sociedad que iba conformándose, tuvo entre otras características una población mayoritariamente masculina, lo cual resulta un dato referencial en la problemática que nos ocupa. Por ejemplo, en 1914 había 133 hombres por cada 100 mujeres; en 1934, 131 hombres por cada 100 mujeres; y en 1947, 109 hombres por cada 100 mujeres. (Castells, 1936: 64)

Si bien, como puede observarse, las proporciones tendieron a equilibrarse, el peso del género en una sociedad eminentemente rural es un elemento preponderante a la hora de evaluar el comportamiento y la inter-relación social de los grupos.

Del mismo modo, cabe indicar también una alta proporción de gente joven; en 1914 el 50\% de la población no llegaba a los veinte años, y para 1947 ese porcentaje se acentuaba, alcanzando al $54 \%$.

Otro aspecto que debe destacarse son las elevadas tasas de ilegitimidad y analfabetismo, que en buena medida revelan las dificultades que tuvo el Estado para asistir con determinados servicios a esta sociedad en permanente expansión.

Por ejemplo, en 1936 la ilegitimidad (es decir, los hijos nacidos fuera del matrimonio) llegaba a un 50\%, alcanzando al 55\% diez años más tarde, cuando a 
nivel país la tasa no llegaba entonces al 27\%. En algunos departamentos del Territorio, como por ejemplo el Martínez de Hoz, se alcanzaba incluso al 62\%.

A su vez, y por la misma época, el analfabetismo en los mayores de 14 años era del 29\%, frente al 13\% registrado en la Argentina en general. La tasa de mortalidad infantil también fue alta: $27 \%$ según datos de la gobernación del Chaco. (Castells, 1936: 76)

Estos son apenas algunos indicadores generales de una población aluvial que crecía vertiginosamente, y cuyas comunidades urbanas y rurales estuvieron expuestas a constantes modificaciones cuantitativas, cualitativas, e incluso en sus lugares de residencia, como ocurrió por ejemplo con el estrato de los obrajeros y cosecheros, expuestos a periódicos traslados debido a las modalidades laborales de sus respectivas actividades.

Dentro de este marco cabe preguntarse de qué manera se desenvolvió una sociedad tan heterogénea y ávida por asegurarse el progreso material en el corto plazo? Qué papel jugaron las instituciones o los hombres públicos para controlar, amalgamar, y eventualmente otorgar identidad a un cuerpo social nuevo, sin unidad, y muchas veces con intereses en conflicto?

En este sentido, cabe recordar que durante las décadas del treinta y cuarenta surgieron dentro o fuera de los Territorios Nacionales algunas figuras que se preocuparon por describir a estos nuevos cuerpos sociales, a veces por simple curiosidad intelectual, pero en la mayoría de los casos, tratando de encontrar fórmulas adecuadas para insertarlos efectivamente en la comunidad nacional, en igualdad de derechos con sus compatriotas, y desde luego, con la asistencia plena del Estado.

Además de los precursores que se ocuparon del tema en las primeras décadas del siglo XX, como Bialet Massé (1904) o Niklison (1915), para esta época y nivel nacional, podríamos mencionar entre otros a Francisco Suáiter Martínez ${ }^{7}$, quien en su condición de observador privilegiado de la vida en estos espacios periféricos, publicó algunas obras en las que describió la idiosincrasia de las sociedades nuevas que aquí se estaban formando, proponiendo algunas medidas para incorporarlas plenamente a la vida nacional.

En su libro Los Territorios, definía a sus comunidades como poseedoras de "un 'tiempo nиеvo', medido por relojes, grávido de futuro, conteniendo apenas el presente, casi desconocedor del pasado. Sus actores no son el gaucho ni el caudillo, sino el maestro de escuela, la mujer, y el inmigrante extranjero".(Suáiter Martínez, 1943: 49)

Aseguraba que:

"La distancia geográfica de los Territorios Nacionales respecto de la capital no es lo más significativo. Lo que verdaderamente importa es la "distancia social" que separa un grupo humano de otro... Hay algunas causas que provocan esta desconexión, y una de ellas es la indiferencia que ronda en los poderes públicos respecto a estas jurisdicciones. A esta actitud se deben los problemas que no se solucionan...”(Suáiter Martínez, 1943: 12-13) 
A nivel local se destacó entre otros Juan Ramón Lestani, quien además de ser una figura referencial en la vida pública del Chaco durante los años treinta, se ocupó particularmente de diagnosticar la problemática de su comunidad y de proponer simultáneamente, medidas de orden práctico para dar cierta homogeneidad, y especialmente "Unidad y Conciencia" -como decía- a esta sociedad cosmopolita. ${ }^{8}$

En sus escritos de la época, una de sus preocupaciones relevantes fue, por ejemplo, hacer conocer las deplorables condiciones de vida que tenían algunos sectores de esta sociedad, en particular aquellos que se desenvolvían en los ámbitos rurales, y de proponer medidas concretas para su reversión. Particularmente en su libro "Oro y Miseria" (1935) contrastó la opulencia de un Territorio que crecía vertiginosamente, con la miseria y el abandono en que se hallaban algunos grupos humanos esenciales para el funcionamiento de la economía territoriana. Consideraba difícultosa la inserción de esta sociedad en el conjunto nacional, si antes no se integraba equitativamente a sus componentes locales.

A menudo se encontró con la apatía, o en el mejor de los casos, con distintos puntos de vista entre quienes tenían las facultades para corregir desequilibrios, o enmendar situaciones injustas.

En tal sentido debe indicarse que otros dirigentes coetáneos también prestaron atención a la problemática derivada de la diversidad del componente social y las condiciones de trabajo en el Chaco rural, pero sus visiones diferían al punto de presentar diagnósticos idealistas, propuestas de corrección antagónicas, o decididamente impracticables.

Con frecuencia las diferencias de opinión estribaron en qué hacer, por ejemplo, para controlar y atender adecuadamente a los nutridos contingentes que periódicamente arribaban al Chaco para participar en las labores manuales de las actividades forestales o agrícolas, y que a la sazón, constituyeron una fuerza laboral imprescindible.

Sin soslayar a otros actores (como los colonos), que por su importancia específica en el proceso ameritarían un estudio exclusivo, hablamos especialmente en esta ocasión de los hacheros y cosecheros, que provenientes en gran número desde jurisdicciones vecinas, por su impacto en la estructura económica y administrativa de esta jurisdicción llegaron a generar cierto debate entre la dirigencia local, y eventualmente a condicionar la instrumentación de políticas públicas desde el nivel nacional.

Una de las cuestiones de interés es la de conocer en qué condiciones vivieron estos representantes típicos del espacio rural, y cuáles fueron sus características, costumbres, y posibilidades de realización en un ámbito promisorio, pero a la vez marginal y deficientemente atendido por las autoridades centrales?

Sabiendo esto es posible contrastar las posiciones sostenidas y calibrar la atención de la dirigencia local respecto a esta cuestión. Del mismo modo, al conocer 
el comportamiento de estos grupos foráneos durante su tiempo de permanencia en el Territorio, podemos también proyectar la influencia de sus pautas culturales en la conformación identitaria de esta sociedad.

Para responder a este interés, podríamos abordar en principio la descripción de las condiciones de vida y trabajo de los tipos sociales más representativos del entorno rural, y caracterizar por ejemplo a los comúnmente llamados "hacheros", personajes emblemáticos de la vida en los obrajes forestales, cuyas iniciales referencias fueron dadas por viajeros ya en la propia época de auge de esta actividad, convirtiéndose en una de las primeras imágenes del Chaco registradas por la sociedad nacional.

\section{UN TIPO HUMANO EMBLEMÁTICO. EL HACHERO Y SUS CONDICIONES DE VIDA Y TRABAJO EN LOS OBRAJES DEL CHACO.}

Durante el apogeo de la actividad forestal en el Chaco, la labor de un "hachero" consistió habitualmente en cortar y procesar árboles previamente seleccionados de "quebracho colorado", que tiene una de las maderas más duras que existen, y a su vez, un alto porcentaje de sustancias tánicas ${ }^{9}$. Los ejemplares buscados eran los más voluminosos (rollizos), de mayor utilidad tanto para la fabricación de vigas como para la extracción de tanino curtiente.

Las tareas se realizaban en pleno monte entre varios hombres en medio de carencias, incomodidades y peligros. Se subdividían en cortadores, picadores, labradores, y carreros, todos bajo la dirección de un capataz. El trabajo era durísimo y se llevaba a cabo desde horas tempranas hasta el crepúsculo, entre enjambres de mosquitos y otras alimañas que acosaban especialmente en los días calurosos.

Al cabo de varias horas de hachado, el quebracho caía en un claro previamente despejado, e inmediatamente se procedía a su trozado y labrado (quitado de corteza) en el mismo sitio. Posteriormente se cargaba esta mole en un alzaprima o "Cachapê", rústico carruaje tirado por bueyes que atravesaba el "varadero" (senda) hacia la vía fluvial más cercana en caso de haberla, o hacia la "playa" ${ }^{10}$ de acopio.

En un día, un grupo de veinte hombres podía "terminar" hasta tres ejemplares, y las labores sólo eran interrumpidas al mediodía para comer una porción de maíz cocido con charque ${ }^{11}$.

Al término de la faena diaria, estos jornaleros retornaban tras larga caminata a sus "ranchos", que no eran más que precarias e insalubres chozas de palo y paja perdidas en la espesura del monte. Según informes sanitarios de la época, la vida de estos hombres raramente se extendía más allá de los cuarenta años en condiciones saludables. ${ }^{12}$

Sobre las condiciones de vida de estos trabajadores, el escritor Juan Ramón Lestani supo expresar su cruda opinión, aunque bastante ajustada a la realidad: 


\begin{abstract}
"Si alguna vez se ha hablado de las condiciones miserables del trabajo humano, hay que poner en primera plana lo que ocurre en los obrajes del Chaco. La inhumanidad del trato es indescriptible; trabajadores como bestias ambulan por las selvas en medio de los constantes peligros naturales, viviendo al abrigo de los árboles, sin vestimenta casi, alimentándose algunas veces con carne que se proveen en la Administración de la empresa, donde se faenan todos los bueyes flacos desahuciados para el trabajo, pues cuando se trata de carne gorda, tiene mejor mercado en la población más cercana. Al obraje va lo último. La carne se convierte en "charqui", y cuando no, se la tiene que comer en pésimo estado, llena de gusanos, lavada y hecha hervir con agua de charcones de los montes, generalmente sucia y verde...

La explotación del trabajador no tiene límites; el contratista roba en el peso, estafa en la medición de calidad, y luego paga el saldo con vales. Estos se canjean en las proveedurías infierno cartaginés-, donde también completan cargándoles los precios en un cien por ciento, pesándose las mercaderías con kilos de 700 gramos, y cuando quedan todavía algunos pesos en el haber del peón, no falta el empresario de taba que invita, donde se esfuman los últimos centavos entre la caña y el juego"(Lestani, 1935: 29-30)
\end{abstract}

En esta época, un obraje forestal medianamente organizado tenía similar configuración a lo que en las zonas ganaderas chaqueñas podría ser el "casco" de una estancia. En una pequeña "pampa" rodeada enteramente por monte nativo, convergían todas las actividades del establecimiento. Desde allí penetraban las "picadas" hacia distintas direcciones, y por las mismas retornaban los "cachapés" con su valioso cargamento hacia la "playa", ubicada en el centro de este claro.

Allí estaba la casa del dueño o administrador (generalmente de ladrillos), y en su periferia, más bien alejadas, se hallaban algunas casuchas de palo y otras de adobe y paja (ranchos) donde vivían las familias de los peones que trabajaban en la "playa". Esta se hallaba cubierta de pilas de leña y rollizos desparramados a la espera de vagones que allí arribaban por improvisados desvíos que solían desprenderse del ramal ferroviario más cercano.(Pavlotzky, 1947: 54)

Los jornaleros de esta "playa" estaban regenteados por el "capataz", que según representaciones típicas de la época, solía ser un "...chinazo regordete y panzón, generalmente ex-agente de policía, exhonerado por sus abusos, pero precisamente por ello, muy buscados por los patrones, ya que sabían "tratar" a la peonada, especialmente a los haraganes..."(Pavlotzky, 1947: 54)

Dentro de la "playa" se ubicaba también la "proveeduría", almacén perteneciente al propio establecimiento, del cual podía sacarse "a cuenta" todo lo que consumía un típico jornalero; alimentos, géneros, ropas, ferretería, artículos de bazar y perfumería, y sobre todo, bebidas alcohólicas.(Pavlotzky, 1947: 55)

En estos obrajes, que podían llegar a tener hasta 500 hacheros, convivían hombres provenientes de distintas regiones, pero fundamentalmente, de las vecinas provincias de Corrientes y Santiago del Estero. Estos se diferenciaban entre sí por su apariencia, por su manera de hablar, sus costumbres, régimen de vida; pero también por sus distintas formas de trabajar, y aún, de reaccionar ante el trato recibido. El correntino era expresivo, activo, con propensión a la rebeldía, y con un fuerte 
sentido de su dignidad. El santiagueño, en cambio, era más tranquilo, menos manifiesto, pero mucho más perseverante; y así como los correntinos eran inmejorables para tumbar un quebracho de varias toneladas, los santiagueños, menos fuertes pero más pacientes, eran maestros en el arte del labrado, que consistía en descortezar prolijamente los troncos y fraccionarlos.(Pavlotzky, 1947: 86-88)

La peligrosidad de estas labores suponía desde luego accidentes de distinta índole, lesiones por golpes de troncos o ramas caídas, mordedura de ofidios; con más frecuencia heridas o mutilaciones por cortes con las hachas, o peor aún, la tuberculosis causada por las pésimas condiciones de vida y alimentación.

En tales casos, la asistencia médica para los afectados era casi una excepcionalidad, confiándose normalmente la atención de los pacientes a los "curanderos" del lugar o zona aledaña. Los tratamientos, basados generalmente en la herboristería, no dejaban sin embargo de ser efectivos ante la falta de otras opciones, sobre todo en lo concerniente a heridas o picaduras ponzoñosas.

Por ejemplo, para la cicatrización y desinfectado, los curanderos aplicaban barro con moho de agua estancada, que daba buen resultado; lo mismo acontecía con las mordeduras de víbora, para las que -independientemente de la especie-, el antídoto recomendado era la masticación de la cáscara de la raíz del "Palo Mataco". (Pavlotzky, 1947: 63-65)

Ahora bien, todo este conjunto de hombres después de cinco o seis jornadas continuas de dura labor, sólo podía encontrar entretenimiento en las "tabeadas"13 de los fines de semana, que a la sazón, eran una de las pocas ofertas de esparcimiento que disponía este entorno.

El juego de "taba", muy común y extendido en los ámbitos rurales de la Argentina solía acarrear consecuencias no deseadas, especialmente para los empleadores. Al desarrollarse en parajes relativamente distantes a los establecimientos forestales, los hacheros se ausentaban por varios días luego de un fin de semana de diversión y alcohol, abandonando literalmente sus labores. Precisamente por esta combinación, estos eventos terminaban casi siempre con pleitos, riñas y heridos.

La irrefrenable propensión a este juego entre los jornaleros, sumada a las pérdidas antedichas, motivó que algunos establecimientos terminaran permitiendo estas actividades dentro de sus predios, con lo cual se garantizaban por un lado las ventas (de bebidas alcohólicas) de la propia proveeduría en esos días, y por otro, la normal prestación laboral desde el mismo inicio de la semana, y hasta incluso, se asegura que se lograba un aumento en la productividad.(Pavlotzky, 1947: 93-94)

Sobre el tema de las condiciones de vida en los obrajes también supo pronunciarse una tradicional entidad vinculada a los intereses de esta región -la Asociación Fomento de los Territorios Chaco y Formosa-14, que oportunamente dejó sus sugerencias al Poder Ejecutivo Nacional, lo cual puso de manifiesto la dimensión y persistencia de esta problemática. 
En un informe de diagnóstico y propuestas respecto a las características de trabajo y medio social de los obrajes, se propusieron algunas medidas correctivas, aunque no siempre atinadas. Por ejemplo en cuanto al funcionamiento de las proveedurías, si bien afirmaban que la mayoría de los administradores de los obrajes no tenía interés en este negocio -aunque instalaban bocas de expendio a fin de evitar males mayores ya que no había otra manera de abastecer a los hacheros-, estimaban sin embargo necesaria una reglamentación de las ya existentes, y mejores controles, por lo cual proponían que debía establecerse la obligatoriedad de vender sólo productos envasados, lo cual permitiría una mayor higiene, y exactitud en los pesos y medidas.

Así mismo, sus precios deberían ser fijados previamente por una Junta Honoraria, y se impondría la obligatoriedad de la emisión de boletas "por duplicado" de cada venta. De la misma forma, deberían colocarse en lugares bien visibles la lista de precios vigente.

Con respecto al alcoholismo, al que consideraban un flagelo entre los trabajadores "del norte del país", y al que juzgaban como un "mal hereditario que era necesario combatir ya que el obrero trabajaba sólo para adquirir el producto", sugerían la supresión total de su venta, castigando severamente a los comerciantes que lo vendiesen, y simultáneamente hacer una campaña de concienciación sobre los daños que ocasionaba su consumo.

En el caso de que estas medidas no surtieran efecto aconsejaban gravar "con patentes elevadas" los locales de expendio a fin de hacerlo prohibitivo; fuertes multas para los transgresores, y "penas corporales" (Sic) para aquellos que por incapacidad económica no puedan oblarlas.

Recomendaron también proveer de agua potable a los trabajadores de los obrajes, haciéndose perforaciones cerca de los establecimientos para evitar el consumo de las represas o charcos.

Pero una de las sugerencias más sorprendentes dentro de esta batería de medidas poco viables para el Chaco de aquella época, fue la de aconsejar una especie de instrucción escolar "ambulatoria" para los hijos de los hacheros que, naturalmente, estaban en permanente movimiento siguiendo la línea de explotación del bosque.

Según esta idea, debían crearse "escuelas móviles" que siguiesen a los campamentos itinerantes, y/o construir Institutos Educativos en puntos estratégicos entre las más importantes explotaciones. Proponían un "servicio de ómnibus" que efectuaría diariamente la búsqueda y retorno de los alumnos entre la escuela y sus "hogares", y añadían que en los locales escolares debería funcionar un comedor solventado por una cooperadora "sostenida por los obrajeros".

Naturalmente, cuesta imaginar un "servicio de ómnibus" en picadas por las que solamente podían pasar los "cachapés", o una regularidad contributiva de los hacheros para sostener la cooperadora de la escuela. 
Como complemento de estas idealistas medidas, sugirieron también construir Centros Sanitarios con consultorios especializados en "enfermedades venéreas, tuberculosis, y tracoma", y una atención general adecuada para "todo el personal de los obrajes y sus familiares".

Por cierto, estas propuestas parecen haber sido hechas por personas que no conocían el Chaco de entonces -lo cual es improbable teniendo en cuenta quiénes las impulsaban-, o sencillamente, las iniciativas fueron una "puesta en escena" para calmar algunas conciencias, o mejorar la imagen pública de sus promotores. ${ }^{15}$

Pero por otra parte, el trabajo en las fábricas de extracto de quebracho, en donde se suponía existían mejores controles, no difería demasiado de las deplorables condiciones en las que se desarrollaba la labor de los hacheros:

"El trabajo del obrero de las fábricas de tanino es rudo, penoso y malsano como pocos. Es también muy peligroso, como lo comprueban los frecuentes accidentes que ocurren en la fábrica. En algunas secciones, la de los toneles en que se hierve el aserrín por ejemplo, se trabaja en un ambiente tan cargado de vapor que impide ver las personas y los objetos colocados a un metro de distancia, y en otras, el aserrín ahoga y enceguece. Por cada abertura del edificio se eleva una columna de vapor, y éste, impregnado de sustancias corrosivas, agujerea y destruye los techos en pocos meses. La luz eléctrica que difícilmente traspasa la enorme masa flotante, la ilumina con claridades de luna. Detrás de ella estalla el estrépito de sus trituradoras, y el incesante, acompasado y pesado jadeo de sus bombas y motores" 16

Debemos recordar en este sentido, que algunas manifestaciones del sistema opresivo en la industria forestal comenzaron a apreciarse durante la rebelión obrera ocurrida en 1921 en inmediaciones de la Compañía "La Forestal", en el norte de Santa Fe, en un movimiento que tuvo repercusiones en el Chaco, donde esta Compañía tenía otros establecimientos. ${ }^{17}$

Aún con estos movimientos que sacaron a la luz una metodología casi feudal en las prácticas laborales, las condiciones de vida y trabajo en las explotaciones forestales no variaron sustantivamente durante las décadas siguientes, tal vez porque la propia declinación de la actividad iniciada a mediados de la década del veinte, tornaba improbable el sacrificio de una ya disminuida rentabilidad en beneficio de los trabajadores.

Aunque parecería una cuestión accesoria, es importante destacar sin embargo el legado cultural dejado en la región por estas grandes masas de jornaleros, que provenientes de las provincias vecinas, terminaron afincándose en apreciable porcentaje cuando declinó la actividad y mudó el ciclo económico.

Especialmente en el sector sud-oriental, donde prevaleció la actividad forestal, quedó conformado un estrato social que impregnaría definitivamente las pautas culturales de sucesivas generaciones en las clases populares del Chaco. Al provenir los hacheros mayoritariamente de la vecina provincia de Corrientes, quedó arraigado ese sedimento cultural tan distintivo como lo es el de la tradición guaraní. 
La entonación del habla y las expresiones típicas como el "sapucai" ${ }^{18}$, las costumbres alimenticias, la música, los dichos y el folklore; la colorida manera de vestir, las creencias y los ritos, y hasta una cierta "tipología física", han quedado hasta hoy como marcas imborrables de la presencia de estos grupos durante los primeros tiempos del Chaco territoriano. La fuerte influencia guaranítica en el sudeste del Chaco sólo puede explicarse a través del conocimiento del llamado ciclo forestal, pero sobre todo, del componente humano involucrado.

\section{EL COSECHERO DE ALGODÓN. ORIGEN, TIPIFICACIÓN, E INFLUENCIA EN LA COMPOSICIÓN DE UN NUEVO CUERPO SOCIAL.}

El "ciclo forestal" comenzó a decaer luego de finalizada la primera guerra mundial, y aunque un número limitado de obrajes y fábricas se mantuvieron en funcionamiento, y hasta tuvieron esporádicos repuntes en los años siguientes, la actividad ya no tendría la misma incidencia que había mostrado hasta ese momento.

Al tiempo en que languidecía la actividad forestal, surgía vigorosamente a partir de la década del veinte, el llamado "ciclo algodonero", con su simultáneo proceso colonizador, su efervescente afluencia humana; nuevas prácticas productivas y laborales, y consecuentemente también, otros problemas en materia social.

La apertura inmigratoria, con incorporaciones étnicas y culturales diversas que vinieron a acompañar el proceso algodonero, transformó previsiblemente el tejido social del Chaco y aparecieron nuevos arquetipos sociales, muy propios de esta etapa.

El denominado "cosechero" o también "bracero" integró juntamente con el "colono" la dupla emblemática de los tipos históricos representativos del período de auge algodonero en el Chaco.

El "cosechero" fue indudablemente uno de los tipos humanos más comunes y extendidos del ámbito rural durante el ciclo algodonero, pero a su vez, integró también uno de los segmentos sociales más "invisibilizados" de esta sociedad en formación. No obstante, por su mayoría numérica y consolidada identidad (ya que provenían de provincias o países limítrofes de arraigadas tradiciones), su periódica y masiva presencia en determinadas épocas del año fue marcando una fuerte impronta en la identidad social del Chaco.

Pero no puede hablarse de un prototipo de características uniformes en el desempeño de este oficio. En los comienzos del ciclo algodonero, las tareas de carpida (cultivo) y recolección del algodón fueron realizadas fundamentalmente por indígenas pacificados, que por ofrecer mano de obra barata, estar adaptados al clima, y resistir la dura labor de la cosecha manual, fueron muy buscados por los colonos. Posteriormente, con la vertiginosa expansión del cultivo y la consecuente 
insuficiencia de los naturales, mediante incentivos oficiales se procuró atraer mano de obra desde las vecinas provincias, o bien del Paraguay.

Es así como anualmente comenzaron a ingresar al Territorio masivos contingentes de cosecheros que traían consigo sus familias, y obviamente también, el acervo cultural propio de estas antiguas jurisdicciones.

Durante sus estadías en el Chaco, que podían prolongarse por un período de cinco o seis meses, si es que participaban de la carpida y de la zafra en sus dos recolecciones, estos grupos convivían en las chacras intercambiando su diversidad cultural. Al término de la campaña, la mayoría regresaba a sus lugares de origen pero aquí quedaban remanentes que se afincaban en calidad de peones o puesteros.

De esta forma, la carga cultural tan distintiva de correntinos, santiagueños y paraguayos iba sedimentando en el Chaco con la reiteración anual de cada ciclo productivo.

Ahora bien; por ser contingentes foráneos destinados a cumplir tareas estacionales, su residencia en el Chaco adquiría un carácter esencialmente temporal e itinerante. La alternancia de chacra en chacra entre y/o luego de las dos pasadas de la zafra motivaba constantes traslados; precarias y promiscuas condiciones de vida en alojamientos temporarios, irregular y deficiente provisión de víveres, y cierta vulnerabilidad a la hora de la negociación de su paga frente al patrón o contratista. ${ }^{19}$

Juan R. Lestani supo describir también las condiciones en las que transcurría la vida cotidiana de estos trabajadores durante sus períodos de permanencia en el Chaco. Decía en 1935:

“...El cosechero que emigra anualmente de su provincia en número de más o menos 25.000 para el levantamiento del algodón, es una víctima de la expoliación común del trabajador. Se lo contrata por determinados precios, pero rara vez se cumple esto. Esta gente trabaja en muy malas condiciones, pues las chacras carecen de galpones de albergue para sus peones, debiendo buscar cada uno de ellos la mejor forma de afrontar las inclemencias del tiempo bajo los árboles, o en mal cubiertos techos de paja. Los altos precios que se fijan por la provisión de comidas y por otras mercaderías de discutible calidad, saldan generalmente los jornales del cosechero..." (Lestani, 1935: 36-37) ${ }^{20}$

Otros funcionarios, entidades y personalidades públicas se ocuparon también y por la misma época de emitir diagnósticos y propuestas sobre las condiciones de residencia en el Territorio de estos nutridos contingentes. En pocos casos sus intereses estaban animados por sentimientos humanitarios, sino más bien por la necesidad de garantizar el retorno de esta imprescindible fuerza laboral en las campañas subsiguientes.

Uno de ellos fue José Castells, quien durante el período en que actuó como gobernador del Chaco (1933-38) se ocupó del tema y creó la Comisión de Braceros en 1935, cuyas funciones serían las de prever las necesidades de mano de obra para las campañas venideras; promover incentivos para atraerla, organizar los traslados y su distribución en las chacras, y asistir a estos grupos una vez instalados. 
Castells instruyó la metodología que debía implementarse para su funcionamiento, y puso especial énfasis en la "selección" que debía practicarse respecto a la composición de los grupos. ${ }^{21}$

Posteriormente, y en función de ponderar el éxito de la labor de esta Comisión, se permitió presentar una imagen casi idílica de las condiciones de vida de los cosecheros en el Chaco. Por ejemplo, respecto al abastecimiento de mercaderías (provista) que generalmente dependía del colono que los contrataba, desautorizó las versiones instaladas en la opinión pública al asegurar que "se habían tejido verdaderas fantasías sobre la expoliación de que eran víctimas los cosecheros en cuanto a los precios de los víveres...”. Al respecto aseguró que se habían fijado los precios de los artículos de primera necesidad, y que "se había hecho cumplir severamente su vigencia..., como así también un estricto control sobre las balanzas que los agricultores usan para pesar el algodón recogido por los braceros" (Castells, 1935: 95-96)

Respecto a otro de los temas esporádicamente cuestionados por algunos medios de prensa (el trabajo de los niños en la cosecha), Castells informó:

"Se ha hablado mucho de la infracción a la ley $\mathrm{N}^{\circ} 11.317$, al permitir que menores se ocupen de la cosecha de algodón. Es de hacer notar que la citada ley hace una excepción, precisamente en los casos en que trabajan menores como miembros de una misma familia. Es el único caso en que trabajan menores en esta tarea -que es la más fácil de las tareas rurales-, representando un esfuerzo mínimo...

Por lo demás, las Subcomisiones conjuntamente con la Policía del lugar, vigilan el cumplimiento estricto de las leyes de trabajo, interviniendo en todos los casos de acuerdo a los términos de la misma..."

Y agregó luego:

"Los hijos del cosechero concurren a cualquiera de las escuelas diseminadas en todo el Territorio, las que aumentan su inscripción enormemente al iniciarse la cosecha. Los menores se instruyen, viven la vida del hogar en un nuevo ambiente que les gusta y con el cual se encariñan. Se aunan esfuerzos, el cosechero se hace optimista, el trabajo le representa un esfuerzo compensado. Trabaja con tesón y no tarda en quedarse definitivamente en el Territorio, en donde la naturaleza feraz lo invita lozana a dedicarle sus esfuerzos y sus energías...

Asi se ha hecho Chaco (sic); así se han levantado sus fábricas, y así se han ido cubriendo sus selvas vírgenes con blancos capullos de algodón que han hecho su riqueza y su brillante porvenir..." (Castells, 1935: 97)

Castells concluyó su opinión sobre la labor de la Comisión de Braceros expresando:

"La fijación del salario mínimo; el control sobre los precios de artículos de primera necesidad; el contralor sobre las balanzas; la represión del juego y la venta de bebidas alcohólicas en las chacras, han servido para demostrar que ha sido una preocupación constante de este gobierno y de la Comisión, el mejorar las condiciones de vida del trabajador, y los 
resultados obtenidos han de ser sus mejores propagandistas para el futuro..." (Castells, 1935: 97)

Otro informe referencial sobre las condiciones laborales y de vida de los cosecheros que arribaban al Chaco en esta época, fue el que confeccionaron los ingenieros agrónomos Rafael García Mata y Rómulo Franchelli, quienes en su condición de representantes de la Junta Nacional del Algodón ${ }^{22}$ hicieron entre 1939 y 1941 una precisa evaluación de estas cuestiones intentando demostrar las ventajas que reportaría la mecanización de la cosecha algodonera para resolver, entre otras cosas, la problemática humana devenida de las tareas manuales de zafra.

En el informe definieron a la masa de cosecheros inmigrantes de otras provincias como "mano de obra adventicia", la cual, si bien reconocían que aportaba un valioso recurso para la zafra, "dicha solución estaba lejos de satisfacer las más elementales exigencias de la dignidad humana" (Mata-Franchelli, 1942: 11) ${ }^{23}$

La postura de los autores a lo largo de su informe, fue que la mecanización de la cosecha evitaría la explotación del bracero, "germen permanente de disturbios sociales como consecuencia de su lamentable situación económica" (MataFranchelli, 1942: 12)

En el mismo se explayaron acerca de las condiciones de vida de estos cosecheros, advirtiendo desde un principio que "nada nuevo se agregaría si se afirma que sus condiciones de vida durante su estadía son muy precarias" (Mata-Franchelli, 1942: 15)

Sobre el alojamiento de los grupos, aclararon que no todos los agricultores disponían de espacios aptos para ese fin, por lo que era habitual la construcción por parte de los propios braceros, de viviendas muy rudimentarias, y las fotografías con que ilustran el tema, son en tal sentido muy representativas.

Sobre su alimentación aseguraron que al depender del abastecimiento de la provista por parte de sus contratistas, los cosecheros pagaban en promedio entre un 20 y un $30 \%$ más elevados los precios de las mercaderías. De la misma manera, y en relación a otro de los temas controvertidos, afirmaron que el $60 \%$ de los cosecheros era analfabeto, y respecto a sus hijos, debido a que también participaban en la recolección, no podían asistir a la escuela, o en el mejor de los casos, eran retirados de ella, con lo cual también en este sentido desacreditaban las afirmaciones hechas por el gobernador Castells apenas tres años antes.(Mata-Franchelli, 1942:15)

Referencias adicionales ofrecen cuando caracterizan las diferentes particularidades de los cosecheros correntinos y santiagueños respectivamente, los que a la sazón, integraron los grupos mayoritarios de esta masa laboral, y cuya periódica afluencia marcó una fuerte impronta en la conformación identitaria de la sociedad chaqueña.

Al respecto señalaron que la idiosincrasia del bracero correntino difería por completo de la del santiagueño, ya que por ejemplo, los primeros se dirigían a la 
cosecha del algodón más por costumbre o tradición, que para obtener un beneficio económico.

Procuraron demostrar sus argumentos al explicar que cuando se realizaba alguna fiesta, ya fuese religiosa o de otro carácter en sus lugares de origen, los correntinos concurrían a las mismas para regresar luego a la cosecha, aún con todos los gastos y pérdida de días de trabajo que esto les suponía. Otro ejemplo que usaron para justificar esta afirmación, fue el hecho de que según sus observaciones, al término de la cosecha los correntinos retornaban a sus "Pagos" sin llevar un solo centavo de lo ganado.

En cambio el santiagueño -indicaban-, es mucho más interesado y trata en todo momento de reunir la mayor cantidad de dinero posible, aún a costa de su propia comodidad. Dicen haber comprobado incluso el caso de familias santiagueñas que con lo ganado en la cosecha en el Chaco, habían podido construir su casa en sus lugares de origen.(Mata-Franchelli, 1942:13)

Naturalmente, las zonas en las que con preferencia se concentraban los correntinos eran la sud-este del Chaco (próxima a Corrientes), hasta las inmediaciones de Sáenz Peña (centro), mientras que los santiagueños se expandían desde este punto hacia el sud-oeste; y a su vez, desde Sáenz Peña hacia el norte, la zona algodonera vinculada a Pampa del Infierno y Concepción del Bermejo, era atendida por cosecheros "golondrina" que venían de las provincias de Salta y Tucumán. ${ }^{24}$

El área circundante a la ciudad de Sáenz Peña (que ocupa el centro geográfico del Chaco), tradicionalmente representó una divisoria nítida en lo que respecta a la distribución de los cosecheros de distintas procedencias. Este no es un dato menor, por cuanto hasta hoy en día, precisamente en la zona aledaña a Sáenz Peña puede notarse casi instantáneamente la confluencia de distintas maneras de hablar de la gente, así como también, de hábitos y costumbres que se reafirman con elocuente claridad, según se circule hacia el norte o el sud-oeste del Chaco. Todavía en la actualidad, un viajero corriente puede notar los repentinos cambios en la tonada del habla, donde el acento correntino (propio de la influencia guaraní) y tan presente en el sud-este, se desdibuja y es reemplazado por el santiagueño o el salteño (de influencia quechua), según el rumbo que se tome. Esta es la diferencia más evidente en las primeras impresiones, pero se agregan otras que se extienden a diversos aspectos de la vida cotidiana de los lugareños. Aquí se percibe nítidamente la influencia de estos grupos de trabajadores temporarios en la base cultural del Chaco.

Ahora bien; dentro de esta masa humana que afluía periódicamente al Territorio había además ciertos patrones comunes de conducta o costumbres relativamente uniformes, y cabría en tal sentido adelantar algunas generalizaciones con base en los registros documentales. Algunos datos interesantes se muestran por ejemplo respecto a la nupcialidad, ya que las uniones matrimoniales se producían en su mayoría en la misma época del año, casi sincrónicamente al término de la zafra algodonera. 
Según datos de oficiales, durante 1936 se concretaron 1.657 casamientos, y las memorias gubernativas son coincidentes en señalar que durante 1934,1935 y 1936, la mayor parte de los enlaces se produjo entre los meses de junio a septiembre, pero particularmente en agosto, es decir, cuando finalizaban los trabajos de recolección del algodón y los contrayentes disponían de tiempo y dinero. Esto demuestra que hasta en esta importante decisión de vida incidía la actividad algodonera en el Chaco.

Un dato adicional sobre este tema es la nacionalidad de los contrayentes. Teniendo en cuenta que según el censo territorial de 1934 el 14,6\% de la población del Chaco era extranjera, se dio desde luego un importante porcentaje de matrimonios entre hombres extranjeros con mujeres argentinas, el cual osciló para los tres años considerados, en el orden del $17 \%$. A su vez, la franja etaria en la que se casaban los varones iba desde los 20 a 29 años, y en el caso de las mujeres, eran mayoritariamente menores de 20 años.(Castells, 1936: 48-51)

Sin embargo, y como lo apuntáramos en páginas anteriores, la ilegitimidad era muy alta (50\% en términos generales), lo cual revelaba que no había propensión a la legalización de las uniones, y esto a su vez denotaba, entre otras cosas, carencia o deficiencias en la instrucción religiosa.

Son elocuentes en este sentido los comentarios editoriales y/o informes gubernativos que compartían la misma preocupación:

“...La ilegitimidad puede significar un indicador de la mayor o menor cultura de un pueblo y trae en muchos casos, consecuencias inaceptables, como por ejemplo el abandono de los hijos, que son fruto de esas uniones ilegales...

Al producirse el abandono del padre de familia, la madre queda desamparada y los hijos mueren a poco de nacer, o se desarrollan en condiciones inapropiadas, siendo incapaces para el futuro, de ser ciudadanos aptos para el Territorio... A este flagelo debemos imputar la causa del aumento de la mortalidad infantil en el grupo de 1 a 5 años..."

decía el gobernador Castells en su Memoria de 1936. (Castells, 1936: 60) ${ }^{25}$

En este sentido, bien viene aclarar que la Iglesia, institución tradicionalmente inductora de la constitución y cohesión familiar, aún no se había organizado en el Chaco de esta época, y la atención espiritual era desempeñada sólo esporádicamente por algunos misioneros franciscanos. Recién a partir de 1936 y a instancias de este último gobernador, se dieron los primeros pasos para la organización formal de la primera Vicaría Eclesiástica, que se transformaría en Diócesis de Resistencia tres años más tarde, iniciándose de esta forma la labor pastoral de la Iglesia católica en el Chaco, y por tanto, una mejor atención espiritual de esta sociedad.(Mari, 1999:166-169)

Otros datos de interés que sobre esta temática arrojan las fuentes documentales, surgen también como directa consecuencia de la deficiente atención del Estado respecto a estos contingentes que periódicamente arribaban a este espacio, 
lo cual se traducía habitualmente en comportamientos muy particulares de los diferentes grupos en su hábitat rural.

Algunas manifestaciones de esta marginalidad se expresaron por ejemplo en el súbito ascenso de los delitos "contra las personas", en la proliferación de enfermedades respiratorias y venéreas, y hasta en un llamativamente alto porcentaje de suicidios. Algunos de estos fenómenos y prácticas llegaron a constituirse en un verdadero flagelo para el Chaco de estos años, tema éste que por su dimensión y complejidad merecería un tratamiento más exhaustivo que no es posible realizar en esta ocasión, pero que deja abierta la oportunidad para su desarrollo en próximos trabajos.

\section{A MODO DE SÍNTESIS}

El componente humano del Chaco se integró durante el período Territoriano con múltiples aportes provenientes de espacios colindantes y de otras naciones que se sumaron a la originaria población aborigen. Ello dio lugar a la conformación de una sociedad multiétnica, cuyo proceso de construcción identitaria se halla aún inconcluso.

La identificación de los diversos grupos y el estudio de sus costumbres y adaptación al medio representa un mecanismo adecuado para reconstruir secuencialmente los momentos en los cuales cada uno de ellos incidió de manera especial en este proceso. El análisis de sus condiciones de vida y trabajo proporciona a su vez los instrumentos necesarios para auscultar los grados de integración -o marginaciónque velada u ostensiblemente se pusieron en práctica en una sociedad que por ser reciente y todavía en vías de formación, presuntamente debía ser abierta y solidaria.

El estudio de los diversos "tipos sociales" que fueron perfilándose en este nuevo escenario nos puede mostrar los rasgos esenciales de una época, la composición de su sociedad, los patrones de comportamiento, así como también algunos prejuicios y expectativas de sus integrantes.

$\mathrm{Si}$ adicionalmente el enfoque se concentra en aquellos sujetos que no han tenido visibilidad, en esos seres anónimos que "no han tenido historia", pero que paradójicamente han dejado una huella indeleble en la cultura popular, el trabajo puede ofrecer cierta originalidad.

Y precisamente éste ha sido el propósito perseguido con el presente; el de aportar algunas contribuciones para entender mejor el proceso de construcción de la identidad colectiva en el Chaco.

Nos hemos basado para ello en el análisis de las condiciones de vida y trabajo de sectores que aun habiendo sido mayoritarios en su momento, no han sido hasta ahora debidamente ponderados como una influencia decisiva en el proceso de construcción de la identidad local. 
Aunque podríamos haber incluido a otros grupos característicos de las etapas abordadas, hemos preferido centrarnos en aquellos que por su mayoritaria presencia y diseminación territorial, pueden considerarse íconos representativos del ámbito rural del Chaco territoriano, y porque entendemos que su aporte fue decididamente significativo en la construcción de una cultura popular en esta jurisdicción.

Este estudio nos reveló a un cuerpo social que en términos generales, y en sintonía con los valores imperantes en ese tiempo, buscó sobre todo una rápida prosperidad material, aunque esto implicara soslayar algunos principios elementales de solidaridad y compromiso público.

En el caso particular de los jornalizados del mundo rural, si bien fueron una fuerza imprescindible en actividades demandantes de mano de obra masiva y terminaron finalmente formando parte de esta sociedad, no llegaron a participar proporcionalmente de los beneficios de los respectivos procesos, ni tampoco recibieron las atenciones adecuadas por parte del Estado o de sus empleadores directos.

En este sentido debe aclararse como atenuante que si bien el Estado promovió una inmigración intensiva para ocupar este espacio y dotar de mano de obra a las actividades de preeminencia, la dimensión alcanzada por el proceso desbordó la capacidad de control de sus organismos y funcionarios.

Ello se tradujo, por ejemplo, en inadecuados mecanismos de control social, y en una deficiente atención en materia de sanidad, instrucción escolar o espiritual, entre otras cuestiones. El Estado Nacional demostró así estar presente en el direccionamiento del proceso, pero muy ausente en su contralor.

Esta incapacidad fue suplantada por la acción de particulares o entidades privadas que procuraron subsanar deficiencias con los medios a su alcance; la denuncia periodística o literaria en el caso de los primeros; la elevación de propuestas, aunque no siempre atinadas, en el caso de los segundos.

Sus iniciativas, no obstante, servirían a la postre para efectuar correcciones a finales de la década del treinta, cuando los poderes centrales impulsaron el proceso de "argentinización" de los Territorios Nacionales, que supondría una mejor inclusión de estas sociedades en la comunidad nacional, y casi imperceptiblemente también, una etapa preparatoria para la provincialización de algunos de ellos.

Por lo demás, y aún con la precariedad observada en el mundo laboral del Chaco, debe señalarse sin embargo que los vigorosos ciclos económicos de este espacio significaron una oportunidad de supervivencia para sectores que no hallaban inclusión en sus lugares de origen, lo cual debe tenerse en cuenta para relativizar, en parte, sus penosas condiciones de residencia en este Territorio. En muchos casos representaron también la posibilidad de obtener arraigo y trabajo permanente, lo cual les permitió a su vez mantener costumbres y tradiciones que terminaron incorporándose a las pautas culturales de esta sociedad en formación. 
Las bases mismas del comportamiento de las clases populares del Chaco están impregnadas hasta la actualidad del acervo cultural trasplantado por estos contingentes de hacheros y cosecheros correntinos, santiagueños y paraguayos que hicieron sedimentar en esta cosmopolita comunidad, sus dialectos, acentos, música, folklore, comidas, danzas, indumentaria, y hasta sus tipologías físicas particulares.-

\section{CITAS Y NOTAS}

1 La Guerra de la Triple Alianza se libró entre los países aliados Argentina, Brasil y Uruguay, contra el Paraguay, entre 1865 y 1870. La derrota de este último país le implicó pérdidas territoriales importantes, y la definición de su frontera externa con la Argentina debió atravesar por el arbitraje del presidente de Estados Unidos Rutherford Hayes, quien en 1878 falló a favor del Paraguay por la porción territorial que aún quedaba en disputa. A partir de ese momento el límite entre ambos países quedó fijado en el río Pilcomayo, y la Argentina inició el proceso de ocupación efectiva del Chaco Central (hoy provincia de Formosa), y del Chaco Austral (hoy provincia del Chaco), por entonces poblados por tribus indígenas guerreras. Antes de convertirse provincias en la década del cincuenta (s. XX), estos dos espacios fueron organizados como "Territorios Nacionales".

2 La denominación "ciclo forestal" se deriva del período de la historia del Chaco comprendido entre finales de la década de 1880, y 1920-1925. En dicho lapso la actividad económica predominante fue la explotación maderera, tanto para la extracción de tanino curtiente del árbol llamado "quebracho colorado"; como para la fabricación de vigas para construcción y durmientes para vías férreas, de otras especies de madera dura. Esta actividad comenzó su declinación al término de la segunda guerra mundial, cediendo paso al llamado "ciclo algodonero", que adquirió particular fuerza a partir de 1921 y se mantuvo en pleno apogeo durante las décadas del treinta y cuarenta.

3 "Correntinos" son los nativos de la vecina provincia de Corrientes. De la misma manera, los "santiagueños" lo son de la provincia de Santiago del Estero; los "santafesinos", de la provincia de Santa Fe; y los "salteños”, de la provincia de Salta, todas, colindantes al Chaco.

4 Definimos sintéticamente a la identidad colectiva como un conjunto de experiencias comunes, valores compartidos y sentimientos de pertenencia, en este caso específico, con relación a una jurisdicción en proceso de construcción.

5 Empleamos el concepto "cuerpos sociales" aludiendo a los conjuntos humanos que, provenientes de distintas regiones del país o del extranjero, mantuvieron durante los primeros tiempos de residencia en el Chaco, una lógica cohesión que les garantizaba la asistencia recíproca y la preservación de su identidad de origen. Este mismo abroquelamiento se utilizaría, ya en una escala más amplia e inclusiva, cuando durante la segunda mitad de la década del treinta comenzaron a asomar los primeros intentos por adquirir una identidad distintiva por parte de los territorianos frente a sus connacionales.

6 Este trabajo se realizó mediante compulsa documental realizada en los repositorios oficiales regionales (Archivo Histórico de la Provincia del Chaco); nacionales (Archivo General de la 
Nacióny ArchivoHistóricodelaGendarmería Nacional); y privados(Archivos dedescendientes de los gobernadores, de entidades públicas, y de dirigentes del Chaco en la época Territoriana) La investigación se desarrolló esencialmente a partir del análisis de documentación primaria, utilizándose particularmente las memorias e informes de los gobernadores, entidades locales y nacionales, funcionarios de distinto rango y viajeros; la correspondencia entre los gobernadores y el Ministerio del Interior, los boletines oficiales y copiadores de la Secretaría de la Gobernación del Chaco, y también las colecciones de periódicos y revistas locales de la época, particularmente "La Voz del Chaco", y "Estampa Chaqueña". Una parte de la bibliografía, al igual que algunos folletos publicados entre 1920 y 1940, fueron consultados y trabajados en el Archivo Histórico de la Provincia del Chaco. La metodología empleada combina técnicas exploratorias, descriptivas y explicativas.

7 Francisco Suaiter Martínez fue un ensayista que escribió entre 1937 y 1943 cuatro libros que conformaron una tetralogía: I Patria de ayer y de hoy; II Límites Argentinos (la tierra y el hombre); III Buenos Aires, Ciudad y Provincia; IV Los Territorios En este último trazó un interesante perfil de las sociedades territorianas como resultado de sus observaciones personales.

Juan Ramón Lestani fue un periodista y escritor nativo del Chaco. Habitual analista político de su medio, publicó numerosos artículos en diversos órganos de prensa del Territorio, como también algunos ensayos; El Territorio Nacional del Chaco-Geográfico, Económico, Político y Social-.(Oro y Miseria). 1935; Unidad y Conciencia: Aspectos Morales del Chaco. Hacia la formación de la unidad territorial. 1938; y En los Caminos del Chaco: Bocetos Regionales. 1940, entre otros. Fue un activo militante del partido socialista e integró en dos oportunidades el Concejo Municipal de Resistencia (1933-35 y 1940-42). Fue un ardiente defensor de los intereses del Chaco en todos los ámbitos y desde su juventud participó en diversas entidades territorianas, algunas de las cuales se constituyeron en gran medida por su iniciativa; la Unión Territorial del Chaco (1926); la Agrupación Pro-Derechos Territoriales (1930); la Alianza Civil Territorial (1936y la Junta Provincial (1940). En su trabajo "Unidad y Conciencia" del año 1938, Lestani esbozó un perfil de lo que él denominó el hombre "tipo Chaco", fundado en una serie de observaciones personales que tenían en cuenta los condicionamientos del Medio y la evolución material del individuo. Señaló que durante la primera etapa del poblamiento (1878-1900los primeros colonos europeos debieron asistirse recíprocamente ante los peligros y las necesidades que suponía la vida en una tierra hostil y con un clima agreste. Estas adversidades modelaron el carácter, templaron la voluntad y fortalecieron la comunión entre los pioneros. Pero a medida que las condiciones de vida mejoraron y llegaron nuevos contingentes atraídos por las posibilidades de obtener rápida fortuna, el mutualismo inicial derivó en egoísmo y exceso de materialismo. "La lucha por el oro puso sordo a toda otra manifestación que no fuera la del inmediato interés y beneficio personal... En este ambiente agitado, con su modalidad característica se formó el hombre tipo Chaco, cuya psicología es el producto del afán de lucro y del aislamiento e indiferencia a toda cultura". José R. Lestani, Unidad y Conciencia. Aspectos morales del Chaco (Resistencia: S/E, 1938), 10-11

9 La resina obtenida de la molienda del quebracho colorado, llamada "tanino", es utilizada hasta el presente para curtir cueros. Esta especie arbórea diseminada en el Chaco, es la que brinda en mayor abundancia y calidad este producto.

10 Se denominaba "playa" en un obraje, al espacio abierto y plano en donde se acopiaban los rollizos (troncosde quebracho para su selección, y posterior transporte. De la misma manera, 
se asignaba este nombre al espacio amplio y plano que circundaba a las estaciones ferroviarias, en donde también se estacionaban productos o pasajeros (como los jornaleros o cosecheros, por ejemplo), a la espera de su contratación por los dueños de las chacras u obrajes.

11 "Charque" o "Charqui": Son tiras de carne saladas y secadas al sol. De esta forma se obtiene un prolongado período de conservación.

12 Información consignada en el informe de Jorge Elías Niklison (1904, p. 118-124con base en datos suministrados por el Director del Hospital Regional de Resistencia, Dr. Julio Perrando. Además de los irreemplazables informes oficiales de Bialet Massé y Jorge Elías Niklison, sobre algunos aspectos de los obrajes puede verse a Ospital, 1990: 5-23. Sobre la vida cotidiana en los obrajes del Chaco, puede verse también el trabajo de Pompert de Valenzuela, 2010: 22-26.

13 “Tabeada". Juego de azar muy común en el ámbito rural argentino que consiste en arrojar a una distancia de seis a diez metros, una sección (ya secade hueso de la pata del animal vacuno que se llama "Taba". Dicha sección tiene dos lados planos distintos, y según la cara en que caiga, significa "suerte" o "mala suerte" para quien la arrojó. Se juega por dinero, o por cualquier posesión que puedan apostar los jugadores.

14 Esta Asociación fue una de las varias organizaciones civiles que se constituyeron en el Chaco como virtuales intermediarias ante los poderes centrales, al carecer sus habitantes de representación por residir en un Territorio Nacional. Figuraron entre las más conocidas la Unión Territorial del Chaco (1926); la Agrupación Pro-Derechos Territoriales (1930); la Alianza Civil Territorial (1936y la Junta Provincial (1940). Pero esta Asociación Fomento de los Territorios de Chaco y Formosa, creada en 1922 y dirigida por el conocido referente del Chaco, Juan S. Mac Lean, fue la más perdurable, y también la que concretó la mayor cantidad de iniciativas para este Territorio.

15 Los autores de la propuesta fueron los Sres. Agustín Seghezzo y Juan V. Valencia, delegados respectivamente de la Asociación de Productores de la Industria Forestal y Asociación Fomento de los Territorios Chaco y Formosa. (Chaco y Formosa. 1945: 15-17)

16 República Argentina-Departamento Nacional del Trabajo; Boletín $N^{o}$ 32; Julio de 1915, Libro II, Pag.161. Citado por Iñigo Carrera Fracciones y Capas en el Proletariado Chaqueño 1910-50. Los obreros de las desmotadoras de algodón. Programa de Investigación sobre el movimiento de la sociedad argentina PIMSA, Documento de trabajo $\mathrm{N}^{\circ} 8$ (Buenos Aires: PIMSA, 1997), 32

17 Entre 1919 y 1921 hubo una serie de conflictos luctuosos en la región Chaco-Santafesina, que en cierta medida estuvieron en sintonía con movimientos similares ocurridos en otros puntos de la Argentina. En 1920 hubo un fuerte estado de conflictividad entre los obreros y la parte patronal del Ingenio "Las Palmas", ubicado en la localidad homónima de Chaco. Este Ingenio, y tal como han coincidido varios autores, era "un Estado dentro del Estado"; una Compañía de capitales británico-argentinos dedicada a varios rubros -incluyendo el forestal-, con 2000 trabajadores; en donde las condiciones laborales eran tan extensas como opresivas; donde se pagaban bajos sueldos en vales; y donde no era posible comprar mercaderías fuera de la propiedad, ni ejercer el comercio sin autorización de la empresa. En diciembre de 1919 hubo un paro exitoso en el que los trabajadores consiguieron acortar la jornada laboral, y el cobro de haberes en moneda nacional. Sin embargo, en 
mayo de 1920 la Cía. inició una contraofensiva de control obrero con ayuda de miembros de la entonces "Liga Patriótica". Luego de varios incidentes (huelgas y enfrentamientos aisladosel conflicto se agudizó produciéndose un sangriento choque entre obreros y fuerzas de la empresa y la Liga entre el 9 y el 10 de agosto de ese año, con decenas de víctimas. El conflicto culminó el 20 de agosto, luego de la intervención del Ejército. Posteriormente, a comienzos de 1921, se repitieron similares incidentes, y casi por los mismos motivos, en otra de las grandes Compañias enclavadas en el Chaco, "La Forestal", de capitales británicos, monopolizadora de la actividad taninera en Chaco y norte de Santa $\mathrm{Fe}$, y con una estructura productiva y laboral similar a la de "Las Palmas". Precisamente en los pueblos del norte de esta provincia ligados a la actividad de la empresa, se produjeron huelgas y enfrentamientos entre obreros con la policía privada de la Cía. y agentes de la "Liga Patriótica". Dichos conflictos fueron descriptos por la literatura histórica y recreados en el Filme "Quebracho", entre otras muestras. (La bibliografía sobre estos temas es bastante amplia y variada, pero una síntesis de estos conflictos puede hallarse en: Girbal de Blacha, 1993: 5-30; y también en Mc Gee Deutsch, 2003: 129-135).

18 Grito agudo típico de la región litoraleña- norte de Argentina, particularmente de la provincia de Corrientes. Según su entonación y prolongación, significa euforia, victoria, e incluso pena. Se utiliza como guía auditiva en montes, ríos y selvas.

19 Cuando se acentuó la demanda de mano de obra para la carpida o zafra, el gobierno territorial implementó incentivos para atraer brazos, que consistían en el pago del pasaje de venida en ferrocarril, pero no el de regreso. Una vez arribados los contingentes, eran contratados por los colonos que mejor paga ofrecían, y seguidamente eran trasladados a las chacras. La actividad, por mucho tiempo no estuvo fiscalizada, y desde luego, no todos los colonos disponían de lugares destinados específicamente para el alojamiento de estos grupos. Un historiador testigo de la época, nos ofrece este testimonio surgido de sus vivencias en la zona algodonera más importante del Chaco en la década del treinta. “...En tiempos de cosecha, la estación del ferrocarril se hacina de "cosecheros" santiagueños y correntinos, que acampan en la "playa" convertida en una bolsa de colocaciones, a cargo de colonos que tratan de obtener el concurso de los braceros y de llevarlos de inmediato a la chacra. Es pintoresca la disputa cuando escasea la mano de obra, entre los tratantes de parla tan difícil..." (Guido Miranda, Tres Ciclos Chaqueños (Resistencia: Región, 1955), 253-254

20 Según la inspección realizada en el Chaco entre 1939 y 1940 por los Ingenieros Agrónomos Rafael García Mata y Rómulo Franchelli como representantes de la Junta Nacional del Algodón, los precios de las mercancías suministradas a los cosecheros en las chacras, estaban elevados entre un 20 y $30 \%$ con relación a los vigentes en el pueblo más cercano. República Argentina, Ministerio de Agricultura, Junta Nacional del Algodón. Cosecha Mecánica del Algodón. Estudio preparado por los Ingenieros Agrónomos Rafael García Mata y Rómulo Franchelli. (Buenos Aires: Imp Oficial, 1942), 15

21 Por esta época, la entonces Junta Nacional para Combatir la Desocupación se interesó sobre la posibilidad de colocar braceros en el Chaco, y su secretario Mario Molina Pico, visitó el Chaco en una gira de inspección. En esa oportunidad el gobernador Castells le manifestó su temor de que entre los desocupados que pudiesen venir "se filtrara gente indeseable", a lo que el funcionario nacional respondió que “...La Junta seleccionaría a los contingentes, mandándolos paulatinamente y nunca de golpe, a fin de que se pudiera ir experimentando y observando la aptitud de estos peones para las tareas que se les encomendaban...”). En esta 
ocasión, la Junta envió 830 braceros, y a pesar de la "selección” prometida vinieron, según el gobernador, algunos "elementos indeseables", los cuales “...no sólo no trabajaban, sino que intentaban quebrantar la fe y las ansias de progreso que animaba a la mayoría..., y que eran simples aventureros...”. Al respecto, Castells agregó en su Memoria de Gobierno: “...A esta clase de gente, el Chaco (sicno les ofrece ambiente propicio; no los quiere ni los desea. El Chaco (sicnecesita de hombres laboriosos y no rentistas sin propiedades (sic); hombres que luchen por la elevación moral y material de símismos, sin desfallecimientos, sin implorar la caridad de nadie. Para ellos el Chaco (sicles brinda hoy y siempre, tierra apta y gratuita, y la mano protectora del Estado y de los particulares...” (José C. Castells, Memoria presentada al Superior Gobierno de La Nación (Resistencia: Moro,1935), 94

22 La Junta Nacional del Algodón fue creada en 1935.

23 Rafael García Mata y Rómulo Franchelli, Cosecha Mecánica del Algodón. (Buenos Aires: Imp. Oficial, 1942), 11

24 Se llamaba cosecheros "golondrina" a los que, con sus respectivas familias, migraban de una región a otra durante las temporadas de zafra. Por ejemplo era habitual que estas familias, (incluyendo los niñostrabajaran en la vendimia de la región de cuyo, para pasar luego a la "carpida" de algodón en el Chaco; trasladarse posteriormente a la zafra de la caña de azúcar en la provincia de Tucumán, para retornar nuevamente al Chaco a la cosecha algodonera, que se extendía hasta el mes agosto. Al año siguiente, recomenzaban el ciclo.

25 Cabe destacar que la tasa de mortalidad infantil fue para los años 1934,1935 y 1936, del $26,93 \% ; 27,76 \%$; y 26,78\% respectivamente (Castells, 1936:76). Por otra parte, ya en 1934 el gobernador Castells se había mostrado preocupado por este tema, al señalar: “...Un dato de interés que acusa todavía la deficiente formación social de nuestra población, es la cantidad extraordinaria de hijos naturales anotados en los registros civiles; pues de los 703 nacidos en abril, 345 son ilegítimos (en todo ese año hubo 7800 nacimientos). Estos datos indican la existencia de un problema de moralización y responsabilidad que nos afecta, y hay que prestarle la atención que merece...”. José C. Castells, Memoria de Gobierno del Chaco (Resistencia: Moro Hnos,1934), 124

\section{BIBLIOGRAFÍA}

BANDIERI, Susana. Sociedad Civil y Redes de Poder Social en los Territorios Nacionales del Sur: Neuquén, Patagonia Argentina, 1880-1907. Neuquén: Conicet-Universidad Nacional del Comahue, 2008.

BANDIERI, Susana. Cuando crear una identidad nacional en los territorios patagónicos fue prioritario. En: Facultad de Humanidades, Universidad Nacional del Comahue, Revista Pilquen. Sección Ciencias Sociales. Año XI, No 11. (Agosto 2009): 1-5. Disponible en:http://www. Revista-pilquen.com.ar/Ciencias Sociales (acceso Agosto 03, 2009)

BORRINI, Héctor. La Colonización como Fundamento de la Organización Territorial del Chaco (1930-1953). Cuadernos de Geohistoria Regional No. 19. Resistencia: IIGHI-CONICET, 1987. 
BRUNIARD, Enrique. El Gran Chaco Argentino (Ensayo de Interpretación Geográfica). “Geográfica”No.4. Resistencia: Uiveridad Nacional del Nordeste, 1978.

BUNSTORF,Jürgen. "El Papel de la Industria Taninera y de la Economía Agropecuaria en la Ocupación del Espacio Chaqueño". Folia Histórica del Nordeste No. 5, Resistencia-Corrientes, Instituto de Historia, Fac. de Humanidades, UNNE, IIGHI-CONICET (1982): 103-120

CUVARDIC GARCÍA, Dorde. "La construcción de Tipos Sociales en el costumbrismo latinoamericano". Revista de Filología y Linguística XXXIV, 1, (Febrero, 2009): 38-51 Universidad de Costa Rica. San José de Costa Rica. http//filyling@ucr.ac.cr, (acceso agosto 04 de 2010).

FAVARO, Orietta. Realidades contrapuestas a los estados provinciales. Los territorios nacionales (1884-1955). Realidad Económica $N^{o}$ 144, (1997): 79-96.

GIRBAL, Noemí. "Crisis obrajera, estrategias sectoriales y condiciones de trabajo en el Gran Chaco Argentino (1918-1930)". Folia Histórica del Nordeste $N^{o} 11$, Resistencia: IIGHI-CONICET (1993): 5-30.

IÑIGO CARRERA, Nicolás. Fracciones y Capas en el Proletariado Chaqueño 1910-50. Los obreros de las desmotadoras de algodón. Documento de trabajo № 8. Programa de Investigación sobre el movimiento de la sociedad argentina PIMSA, Buenos Aires: PIMSA, 1997.

LEONI, María Silvia. La Conformación del Campo Cultural Chaqueño. Una aproximación. Corrientes: Moglia Ediciones, 2008.

LESTANI, Juan Ramón. Unidady Conciencia. Aspectos Morales del Chaco. Resistencia: S/E, 1938.

LESTANI, Juan Ramón. El Territorio Nacional del Chaco. Geográfico, Económico, Social. (Oro y Miseria). Resistencia: S/Ed., 1935.

MAEDER, Ernesto J. Historia del Chaco. Colección Historia de Nuestras Provincias. № 18 . Buenos Aires: Plus Ultra, 1997

MARI, Oscar Ernesto. El Territorio Nacional del Chaco Durante la Etapa Conservadora 19301943, Cuadernos de Geohistoria Regional No 37, Resistencia: IIGHI-CONICET, 1999.

MC GEE DEUTSCH, Sandra. Contrarrevolución en la Argentina 1900-1932. La liga patriótica argentina. Buenos Aires: Universidad Nacional de Quilmes, 2003.

MIRANDA, Guido. 1955. Tres Ciclos Chaqueños. Crónica Histórica Regional, Resistencia-Chaco, Edit. Norte Argentino.

OSPITAL, María Silvia. Condiciones laborales en la explotación forestal del Gran Chaco Argentino (1890-1920). Folia Histórica del Nordeste Nº 9, Resistencia, IIGHI-CONICET. (1990): 5-23.

PAVLOTZKY, José. Esta Tierra es Mía. Buenos Aires: El Ateneo, 1947

POMPERT DE VALENZUELA, María Cristina. Memorias del Chaco Forestal. Corrientes: Edit. Moglia, 2010

SUAITER MARTÍNEZ, Francisco. Los Territorios. Buenos Aires: Instituto Cultural Joaquín V. González, 1943. 


\section{Fuentes éditas:}

Archivo Histórico de la Provincia del Chaco (En adelante A.H.P.CH.). Gobernación del Chaco. Memoria Presentada al Superior Gobierno de la Nación por el Gobernador José Castells, correspondiente al año 1934. Resistencia, 1935

A.H.P.CH. Gobernación del Chaco. Memoria Presentada al Superior Gobierno de la Nación por el Gobernador José Castells, correspondiente al año 1936. Resistencia, Imp. Juan Moro, 1937

A.H.P.CH. Gobernación del Territorio del Chaco. Memoria presentada al Ministerio del Interior por el gobernador del Territorio Nacional del Chaco, José Castells, correspondiente al año1935.

Republica Argentina, Ministerio de Agricultura, Junta Nacional del Algodón. Cosecha Mecánica del Algodón. Estudio preparado por los Ingenieros Agrónomos Rafael García Mata y Rómulo Franchelli. Buenos Aires, 1942

República Argentina. Informe del Inspector del Departamento del Trabajo, José Elías Niklison. En: Boletín del Departamento Nacional del Trabajo No 32, 1915. 4-147.

República Argentina. Ministerio del Interior. Informe sobre el estado de las clases obreras en el interior de la República por el Dr. Juan Bialet Massé. Buenos Aires, Imprenta de Adolfo Grau, 1904, T.I, Cap.II. 29-96.

A.H.P.CH . Revista Chaco y Formosa. (Órgano de la Asociación Fomento de los Intereses de los Territorios de Chaco y Formosa). Año XIX, No 199, Agosto de 1945. 15-17.

\section{ACERCA DEL AUTOR}

Oscar Ernesto Mari: Doctor en Historia por la Universidad Nacional del Salvador (USAL). Investigador Independiente del CONICET, con lugar de trabajo en el Instituto de Investigaciones Geohistóricas (IIGHI-CONICET), y profesor regular responsable de la cátedra Historia Argentina I de la Facultad de Humanidades de la Universidad Nacional del Nordeste (UNNE) con sede en Resistencia, Chaco, Argentina. Ha publicado seis libros y numerosos artículos en revistas hispanoamericanas, especialmente sobre historia del Nordeste Argentino. Pueden mencionarse entre otras, Mundo Agrario (Arg); Vitruvius (Brasil); Norte Grande (Chile); Anuario de Estudios Históricos; Revista Complutense de H. de América (España); Rev. Secuencia (México); Rev. Historia de América (IPGH). E.Mail: oscar.mari@yahoo.com.ar; omari@bib.unne.edu.ar. Dirección : Av. Arribálzaga 2050 y Pasaje Loma Negra, Resistencia, Chaco, Argentina, C.P.3500. T.E. 054-03722. 472220 